\title{
Solubility and Structure of Calcium Silicate Hydrate
}

Jeffrey J. Chen ${ }^{a \dagger}$, Jeffrey J. Thomas ${ }^{b}$, Hal F. W. Taylor ${ }^{c \ddagger}$, and Hamlin M. Jennings $s^{a b^{*}}$

${ }^{a}$ Northwestern University, Department of Materials Science and Engineering, Evanston, IL 60208;

${ }^{b}$ Northwestern University, Department of Civil and Environmental Engineering, Evanston, IL 60208;

${ }^{c}$ Maudry Bank, Lake Road, Coniston, Cumbria, LA21 8EW, UK

"Corresponding author: Tel: +1-847-491-4858, Fax: +1-847-491-4011

Email addresses: jeff.chen@pole-technologique.lafarge.com (J.J. Chen), h-jennings@northwestern.edu (H.M. Jennings)

† Present address: Lafarge Laboratoire Central de Recherche, 38291 Saint Quentin Fallavier Cedex, France

\$Deceased as of 25 November 2002

Keywords: Calcium silicate hydrate $(\mathrm{C}-\mathrm{S}-\mathrm{H})$, Solubility, Spectroscopy

\begin{abstract}
$\mathrm{C}-\mathrm{S}-\mathrm{H}$, the poorly crystalline calcium silicate hydrate formed in cement paste and aqueous suspension, is characterized by extensive disorder and structural variations at the nanometer scale. An analysis of new and published solubility data for $\mathrm{C}-\mathrm{S}-\mathrm{H}$ formed by different preparation methods and with a broad range of compositions illustrates a previously unrecognized family of solubility curves in the $\mathrm{CaO}-\mathrm{SiO}_{2}-\mathrm{H}_{2} \mathrm{O}$ system at room temperature. As demonstrated by ${ }^{29} \mathrm{Si}$ magic-angle spinning (MAS) NMR data and by charge balance calculations, the observed differences in solubility arise from systematic variations in $\mathrm{Ca} / \mathrm{Si}$ ratio, silicate structure, and $\mathrm{Ca}-\mathrm{OH}$ content. Based on this evidence, the family of solubility curves are interpreted to represent a spectrum of metastable $\mathrm{C}-\mathrm{S}-\mathrm{H}$ phases whose structures range from purely tobermorite-like to largely jennite-like. These findings give an improved understanding of the structure of these phases and reconcile some of the discrepancies in the literature regarding the structure of $\mathrm{C}-\mathrm{S}-\mathrm{H}$ at high $\mathrm{Ca} / \mathrm{Si}$ ratios.
\end{abstract}

\section{Introduction}

Calcium silicate hydrates possess a remarkable level of structural complexity. Over 30 crystalline calcium silicate hydrate phases are known, and for preparations made near room temperature, there is an indefinite range of semi-crystalline to nearly amorphous phases, all of which are described by the generic term, $\mathrm{C}-\mathrm{S}-\mathrm{H}^{\dagger}[1]$; more specific terms are used when necessary. The $\mathrm{C}-\mathrm{S}-\mathrm{H}$ formed from the hydration of tricalcium silicate $\left(\mathrm{C}_{3} \mathrm{~S}\right)$ or $\square$-dicalcium silicate $\left(\square-\mathrm{C}_{2} \mathrm{~S}\right)$, together constituting about $75 \%$ of a portland cement by weight, is a particularly disordered variety, usually called $\mathrm{C}-\mathrm{S}-\mathrm{H}$ gel to distinguish it from 'synthetic' preparations of $\mathrm{C}-\mathrm{S}-\mathrm{H}$ such as the reaction of $\mathrm{CaO}$ and $\mathrm{SiO}_{2}$ or the double decomposition of

\footnotetext{
${ }^{\dagger}$ In cement chemistry notation, $\mathrm{C}=\mathrm{CaO}, \mathrm{S}=\mathrm{SiO}_{2}$, and $\mathrm{H}=\mathrm{H}_{2} \mathrm{O}$.

$¥$ Labeling these preparations as 'synthetic' is somewhat arbitrary, as all preparations of $\mathrm{C}-\mathrm{S}-\mathrm{H}$ studied here, including those formed from $\mathrm{C}_{3} \mathrm{~S}$ or from cements, are artificially synthesized. Nevertheless, we will adhere to custom for lack of a better term.
} 
a Ca-salt and an alkali silicate in aqueous solution. The composition of $\mathrm{C}-\mathrm{S}-\mathrm{H}$ can vary, and the dashes in the term ' $\mathrm{C}-\mathrm{S}-\mathrm{H}$ ' indicate that no specific composition is implied.

The nanostructure of $\mathrm{C}-\mathrm{S}-\mathrm{H}$ is defined by its variations, and a comprehensive understanding requires an explanation of how variations of the $\mathrm{Ca} / \mathrm{Si}$ ratio, the silicate structure, and the contents of $\mathrm{Si}-\mathrm{OH}$ and $\mathrm{Ca}-\mathrm{OH}$ are correlated. Although recent spectroscopic studies (see Section 1.3) have identified the prominent mechanisms responsible for these variations, a framework to synthesize this knowledge into a comprehensive understanding of $\mathrm{C}-\mathrm{S}-\mathrm{H}$, particularly at high $\mathrm{Ca} / \mathrm{Si}$ ratios, is lacking. New relationships reported here between solubility and structure appear to fill this void, as they show that the structural variations occur within a spectrum of related metastable phases at high $\mathrm{Ca} / \mathrm{Si}$ ratios.

Brief reviews of the structure of $\mathrm{C}-\mathrm{S}-\mathrm{H}$ and of equilibria in the $\mathrm{CaO}-\mathrm{SiO}_{2}-\mathrm{H}_{2} \mathrm{O}$ system at room temperature follow.

1.1. Relation to crystalline phases. Much of our knowledge of the nanostructure of $\mathrm{C}-\mathrm{S}-\mathrm{H}$ has been obtained from structural comparisons with crystalline calcium silicate hydrates, 1.4-nm tobermorite and jennite being the most appropriate models.

The structure of 1.4-nm tobermorite, $\mathrm{Ca}_{5} \mathrm{Si}_{6} \mathrm{O}_{16}(\mathrm{OH})_{2} \cdot 8 \mathrm{H}_{2} \mathrm{O}$, which has only been recently solved by single crystal diffraction methods [2], has long been known to be based on a composite layer composed of a distorted central $\mathrm{Ca}-\mathrm{O}$ sheet that is ribbed on either side with single ${ }^{\S}$ dreierketten [7,8], i.e., silicate chains that repeat at intervals of three silicate tetrahedra. Two of these tetrahedra, called paired tetrahedra, share two oxygen atoms with the central $\mathrm{Ca}-\mathrm{O}$ sheet, while the third, called a bridging tetrahedron, shares only one (Figure 1). The particular conformation of a dreierkette reflects the need for the silicate chain to conform to the interatomic spacings of the $\mathrm{Ca}-\mathrm{O}$ sheet, which itself is dictated by the coordination requirements of the $\mathrm{Ca}$ cation. The interlayer spaces of 1.4-nm tobermorite contain water molecules and additional $\mathrm{Ca}$ cations (i.e., interlayer $\mathrm{Ca}$ ), which balance the negative charge of the composite layer. The $\mathrm{Ca} / \mathrm{Si}$ ratio of $1.4-\mathrm{nm}$ tobermorite is 0.83 , but, as will be discussed, this value can easily vary in less crystalline forms.

The crystal structure of jennite, $\mathrm{Ca}_{9}\left(\mathrm{Si}_{6} \mathrm{O}_{18}\right)(\mathrm{OH})_{6} \cdot 8 \mathrm{H}_{2} \mathrm{O}$, has only very recently been determined by direct methods [9], though the $\mathrm{Ca}-\mathrm{O}$ part and some other features were suggested on crystal chemical grounds in an otherwise imperfect model of the structure in 1968 [10]. As with 1.4-nm tobermorite, the structure is based on layers in which a central $\mathrm{Ca}-\mathrm{O}$ sheet is flanked on both sides by rows of single dreierketten, together with interlayer $\mathrm{Ca}$ atoms and water molecules. An important difference between 1.4-nm tobermorite and jennite is that every other dreierkette is replaced by a row of OH groups. This substitution causes a considerable corrugation of the $\mathrm{Ca}-\mathrm{O}$ layers in jennite, which have the empirical formula $\mathrm{Ca}_{2} \mathrm{O}_{5}$; some of the $\mathrm{O}$ atoms in this layer are shared with dreierketten, the paired tetrahedra of which are inset within the corrugations, while others form parts of water molecules and $\mathrm{OH}$ groups. These $\mathrm{OH}$ groups are balanced entirely by $\mathrm{Ca}$, thus creating $\mathrm{Ca}-\mathrm{OH}$ bonds; unlike previously believed, there are no $\mathrm{Si}-\mathrm{OH}$ bonds in well-crystallized jennite [9]. The $\mathrm{Ca} / \mathrm{Si}$ ratio of jennite is 1.5 , which can increase in less crystalline forms as in 1.4-nm tobermorite.

1.2. Less-crystalline phases: $\mathbf{C}-\mathbf{S}-\mathbf{H}(\mathbf{I}), \mathbf{C}-\mathbf{S}-\mathbf{H}(\mathbf{I I})$, and $\mathbf{C}-\mathbf{S}-\mathbf{H}$ gel. An important characteristic of the structures of 1.4-nm tobermorite and jennite is their ability to vary in composition, degree of

\footnotetext{
$\S$ Since C-S-H generally only contains single dreierketten (except occasionally at $\mathrm{Ca} / \mathrm{Si}$ ratios near $0.7[3,4]$ ), 1.4$\mathrm{nm}$ tobermorite is considered a more appropriate structural model for $\mathrm{C}-\mathrm{S}-\mathrm{H}$ than 1.1-nm tobermorite [5] or clinotobermorite [6], which have double dreierketten.
} 
polymerization, and extent of crystallinity while maintaining the essential features of the composite layer structure.

When $\mathrm{CaO}$ and $\mathrm{SiO}_{2}$, or an alkali silicate and a Ca-salt, or (under certain conditions) calcium silicates such as $\mathrm{C}_{3} \mathrm{~S}$ or $\square-\mathrm{C}_{2} \mathrm{~S}$ are reacted at room temperature in dilute aqueous suspension, an imperfect version of 1.4-nm tobermorite, called $\mathrm{C}-\mathrm{S}-\mathrm{H}(\mathrm{I})$, generally results. X-ray diffraction (XRD) powder patterns consist largely of $h k 0$ bands of 1.4-nm tobermorite and sometimes a broad basal reflection, all of which suggests a material having little more than two-dimensional order. $\mathrm{C}-\mathrm{S}-\mathrm{H}(\mathrm{I})$ can accommodate a substantial concentration of defects such as the omission of bridging tetrahedra [11], or variations in the contents of interlayer $\mathrm{Ca}$ and of protons attached to $\mathrm{Si}-\mathrm{O}^{-}$[12]. These changes allow variations in $\mathrm{Ca} / \mathrm{Si}$ ratio, ranging from $0.67-1.5$. Single dreierketten have been confirmed by ${ }^{29} \mathrm{Si} \mathrm{NMR}$ and by trimethylsilylation (TMS), the latter showing that the removal of bridging tetrahedra fragments the infinite silicate chains into segments containing 2, 5, 8,..(3n-1) tetrahedra [13-15]. The mean chain length, measured by ${ }^{29} \mathrm{Si} \mathrm{NMR}$, increases with decreasing $\mathrm{Ca} / \mathrm{Si}$ ratio, particularly below a $\mathrm{Ca} / \mathrm{Si}$ ratio of $1.1-1.3[3,4,16-20]$.

In the prolonged reaction of $\mathrm{C}_{3} \mathrm{~S}$ or $\square-\mathrm{C}_{2} \mathrm{~S}$ with excess water, several studies [21-23] have identified a unique compound called C-S-H(II). Recent attempts [3] to form C-S-H(II) have been unsuccessful, as some of the details on preparation remain obscure. Nevertheless, X-ray and electron diffraction, infrared (IR) spectroscopy, and compositional analysis suggest that $\mathrm{C}-\mathrm{S}-\mathrm{H}(\mathrm{II})$ is an imperfect version of jennite, much as $\mathrm{C}-\mathrm{S}-\mathrm{H}(\mathrm{I})$ is to $1.4-\mathrm{nm}$ tobermorite [22]. The $\mathrm{Ca} / \mathrm{Si}$ ratios of the $\mathrm{C}-\mathrm{S}-\mathrm{H}(\mathrm{II})$ preparations have had $\mathrm{Ca} / \mathrm{Si}$ ratios near 2 .

The reaction of $\mathrm{C}_{3} \mathrm{~S}$ or $\square-\mathrm{C}_{2} \mathrm{~S}$ with about half their weight of water produces a hardened paste containing two products: $\mathrm{C}-\mathrm{S}-\mathrm{H}$ gel and $\mathrm{Ca}(\mathrm{OH})_{2}(\mathrm{CH})$. C-S-H gel is even less ordered than $\mathrm{C}-\mathrm{S}-\mathrm{H}(\mathrm{I})$ or $\mathrm{C}-\mathrm{S}-\mathrm{H}(\mathrm{II})$ : its XRD powder pattern consists of a broad band at 0.26-0.32 nm and a sharper peak at $0.182 \mathrm{~nm}$. These spacings correspond to the most prominent repeats in the $\mathrm{Ca}-\mathrm{O}$ layers of both tobermorite and jennite, so it is impossible to conclude solely from XRD evidence which structure better approximates the nanostructure of $\mathrm{C}-\mathrm{S}-\mathrm{H}$ gel. Determinations of the contents of $\mathrm{CH}$ and of residual $\mathrm{C}_{3} \mathrm{~S}$ [24,25], and microanalyses using the microprobe [26-28] or the TEM [29-31] indicate a $\mathrm{Ca} / \mathrm{Si}$ ratio in C-S-H gel of 1.7-1.8. These observations, combined with other evidence from silicate structure, local variations in $\mathrm{Ca} / \mathrm{Si}$ ratio, selected area electron diffraction patterns, thermogravimetric curves, and density have led to the hypothesis that $\mathrm{C}-\mathrm{S}-\mathrm{H}$ gel is initially a mixture of tobermorite- and jennite-like structures, the latter becoming increasingly dominant, and ultimately solely present, with age [32].

1.3. $\mathbf{S i}-\mathbf{O H}$ and $\mathbf{C a}-\mathbf{O H}$ in $\mathbf{C}-\mathbf{S}-\mathbf{H}$. Together with $\mathrm{Ca} / \mathrm{Si}$ ratio and silicate structure, $\mathrm{Si}-\mathrm{OH}$ and $\mathrm{Ca}-\mathrm{OH}$ groups are important in determining the nanostructure of $\mathrm{C}-\mathrm{S}-\mathrm{H}$. The variations in the contents of $\mathrm{Si}-\mathrm{OH}$ and $\mathrm{Ca}-\mathrm{OH}$, discussed below, are central to variations in structure at high $\mathrm{Ca} / \mathrm{Si}$ ratios, as discussed in Section 5.

${ }^{17} \mathrm{O}$ NMR [33] and IR [12] spectroscopy both show that the content of $\mathrm{Si}-\mathrm{OH}$ in $\mathrm{C}-\mathrm{S}-\mathrm{H}$ decreases with increasing $\mathrm{Ca} / \mathrm{Si}$ ratio, the latter technique showing that it goes to zero at a $\mathrm{Ca} / \mathrm{Si}$ ratio of $\sim 1.2-1.3 .{ }^{1} \mathrm{H}$ NMR studies [34,35] are consistent with these findings as they indicate the absence of $\mathrm{Si}-\mathrm{OH}$ groups in $\mathrm{C}-\mathrm{S}-\mathrm{H}$ gel of hydrated $\mathrm{C}_{3} \mathrm{~S}$ and $\square-\mathrm{C}_{2} \mathrm{~S}$ pastes. These results suggest that with increasing $\mathrm{Ca} / \mathrm{Si}$ ratio, $\mathrm{Ca}$ ions not only substitute for bridging tetrahedra but also for protons in $\mathrm{Si}-\mathrm{OH}$ groups. These mechanisms are important for varying the $\mathrm{Ca} / \mathrm{Si}$ ratio at low values.

$\mathrm{Ca}-\mathrm{OH}$ bonds have been detected in $\mathrm{C}-\mathrm{S}-\mathrm{H}$ above $\mathrm{Ca} / \mathrm{Si}$ ratios of 1 by ${ }^{17} \mathrm{O}$ NMR [33], ${ }^{1} \mathrm{H}$ NMR $[4,34]$, IR spectroscopy [12], and inelastic neutron scattering (INS) [36]. ${ }^{29} \mathrm{Si}$ NMR and charge balance 
considerations $[3,12]$ suggest that $\mathrm{Ca}-\mathrm{OH}$ groups form in $\mathrm{C}-\mathrm{S}-\mathrm{H}$ at high $\mathrm{Ca} / \mathrm{Si}$ ratios only after all protons in $\mathrm{Si}-\mathrm{OH}$ groups have been replaced with $\mathrm{Ca}$. Klur et al. [4] have further shown through dipolar ${ }^{1} \mathrm{H}-{ }^{29} \mathrm{Si}$ correlation maps that the protons in the $\mathrm{Ca}-\mathrm{OH}$ groups are within $\sim 5 \AA$ from $\mathrm{Si}$ atoms, thus confirming that the $\mathrm{Ca}-\mathrm{OH}$ sites are in $\mathrm{C}-\mathrm{S}-\mathrm{H}$ rather than in small regions of amorphous $\mathrm{CH}$ undetectable by X-rays. A recent INS study [36] showed that $23 \%$ of the $\mathrm{Ca}$ in $\mathrm{C}-\mathrm{S}-\mathrm{H}$ gel of a 8 -month hydrated $\mathrm{C}_{3} \mathrm{~S}$ paste was balanced by $\mathrm{OH}$; assuming that these $\mathrm{Ca}-\mathrm{OH}$ bonds occur in the main $\mathrm{Ca}-\mathrm{O}$ layer (see below), this high value, which is close to the $33 \%$ value for jennite, was considered circumstantial evidence that $\mathrm{C}-\mathrm{S}-\mathrm{H}$ gel resembles a jennite-like $\mathrm{C}-\mathrm{S}-\mathrm{H}$ at late times. Upon decalcification of the $\mathrm{C}_{3} \mathrm{~S}$ paste, the $\mathrm{Ca}-\mathrm{OH}$ content decreased linearly with decreasing $\mathrm{Ca} / \mathrm{Si}$ ratio, until reaching a negligible value at $\mathrm{Ca} / \mathrm{Si} \sim 1[36]$.

Location of $\mathrm{Ca}-\mathrm{OH}$ bonds. $-\mathrm{Ca}-\mathrm{OH}$ bonds can occur either in the main $\mathrm{Ca}-\mathrm{O}$ layer, at interlayer sites, or at surface sites, and current evidence cannot unambiguously determine the preferred site in $\mathrm{C}-\mathrm{S}-\mathrm{H}$. However, it appears unlikely that the primary sites for $\mathrm{Ca}-\mathrm{OH}$ are at surfaces (where bond valences are unsatisfied), since this would imply that the $\mathrm{Ca}-\mathrm{OH}$ content scales with the surface area of $\mathrm{C}-\mathrm{S}-\mathrm{H}$; this does not agree with water adsorption [37,38] and recent small-angle neutron scattering (SANS) [39] studies showing that the greatest specific surface area in $\mathrm{C}-\mathrm{S}-\mathrm{H}$ occurs at low $\mathrm{Ca} / \mathrm{Si}$ ratios (i.e., near 1), where charge balance [3,12] and INS [36] data show the lowest $\mathrm{Ca}-\mathrm{OH}$ content. The evidence between interlayer and main layer $\mathrm{Ca}-\mathrm{OH}$ sites is less clear, but the latter appears more likely since nearly all $\mathrm{Ca}-\mathrm{OH}$ bonds in 1.4-nm tobermorite [2] and jennite [9] are from main layer Ca. Assuming this is true in $\mathrm{C}-\mathrm{S}-\mathrm{H}$, the $\mathrm{Ca}-\mathrm{OH}$ in the main layer can occur randomly (as in a solid solution) or in a more organized fashion as in jennite (at least in small regions); however, when the $\mathrm{Ca}-\mathrm{OH}$ content is high (as in $\mathrm{C}-\mathrm{S}-\mathrm{H}$ gel), it would seem more likely that a jennite-like structure would eventually result due to a driving force to organize into a more (locally) ordered structure.

\section{Equilibria in the $\mathrm{CaO}-\mathrm{SiO}_{2}-\mathrm{H}_{2} \mathrm{O}$ system at room temperature}

2.1. Comments on thermodynamic equilibrium. Equilibria in the $\mathrm{CaO}-\mathrm{SiO}_{2}-\mathrm{H}_{2} \mathrm{O}$ system gives insight into the structure of $\mathrm{C}-\mathrm{S}-\mathrm{H}$ since the solubility of $\mathrm{Ca}$ and $\mathrm{Si}$ in a contacting aqueous phase must be tied thermodynamically (via chemical potentials) to the underlying structure of the solid. However, as might be expected from a solid with such an impressive variability in composition and structure, thermodynamic and kinetic ambiguities abound in any equilibrium associated with $\mathrm{C}-\mathrm{S}-\mathrm{H}$. Several important issues are discussed below.

According to the Gibbs phase rule, when the 3-component $\mathrm{CaO}-\mathrm{SiO}_{2}-\mathrm{H}_{2} \mathrm{O}$ system has a solid $(\mathrm{C}-\mathrm{S}-\mathrm{H})$ and liquid (aqueous solution) phase in equilibrium at fixed temperature and pressure, there is only one degree of freedom, a mole fraction in either phase. Thus, when altering the Ca concentration in aqueous solution (the most easily adjustable parameter), the Si concentration of the same aqueous phase and the $\mathrm{Ca}$ and $\mathrm{Si}$ concentrations in the solid (i.e., the solid $\mathrm{Ca} / \mathrm{Si}$ ratio) adjust accordingly until the chemical potentials of the components in both phases are equal (i.e., $\square_{i}^{\text {liquid }}=\square_{i}^{\text {solid }}$ ). This process reduces the system's Gibbs free energy to a global minimum if a true equilibrium is established, but in many real systems (with kinetic or energetic barriers), only a local minimum is achieved, thereby restricting the equilibrium to a metastable state. The ill-crystallized $\mathrm{C}-\mathrm{S}-\mathrm{H}$ phases that form at room temperature and ordinary pressure (e.g., C-S-H(I), C-S-H gel) are good examples of metastable phases, since they persist indefinitely although crystalline calcium silicate hydrates such as afwillite [40,41] and presumably 
tobermorite and jennite have a lower free energy. The equilibrium between $\mathrm{C}-\mathrm{S}-\mathrm{H}$ and an aqueous phase discussed herein is thus strictly a metastable equilibrium.

It is inevitably uncertain whether solubility data for $\mathrm{C}-\mathrm{S}-\mathrm{H}$ represent true equilibrium concentrations; the incongruent dissolution and the metastability of $\mathrm{C}-\mathrm{S}-\mathrm{H}$ further contributes to the ambiguity. In fact, there is no experimental measurement that can conclusively confirm the attainment of equilibrium. Even the occurrence of apparent steady-state concentrations is insufficient evidence for thermodynamic equilibrium due to the possibility that the concentrations are being dictated by kinetics (i.e., diffusion) rather than thermodynamics. A more rigorous (although still fallible) approach is to ensure that the same solubility is obtained from the decalcification of a high $\mathrm{Ca} / \mathrm{Si}$ ratio solid and the recalcification of a low $\mathrm{Ca} / \mathrm{Si}$ ratio solid ${ }^{\dagger}$. If agreement is found, there is some assurance that the equilibrium is at least locally stable to small perturbations in composition, thus suggesting a metastable equilibrium. The terms decalcification and recalcification implicitly reflect the fact that, except for $\mathrm{Ca} / \mathrm{Si}$ ratios between $0.7-0.8$ where the dissolution is congruent $[42,43]$, the transfer of mass between solid and aqueous solution is almost entirely of $\mathrm{CaO}$, especially at high solid $\mathrm{Ca} / \mathrm{Si}$ ratios, where the dissolution is most strongly incongruent.

It is important to note that the stability of this metastable equilibrium is only explicitly illustrated for the duration of a solubility experiment, typically several weeks to several months. After this period, perhaps after several years, the equilibrium position of this system could very well shift to an alternative metastable state of lower free energy due to structural changes in $\mathrm{C}-\mathrm{S}-\mathrm{H}$ that accompany aging [44]. In fact, a series of such metastable states is thermodynamically possible, and the results presented here will provide more explicit boundaries.

2.2. Previous solubility relations. Since Le Chatlier's classic studies on $\mathrm{C}-\mathrm{S}-\mathrm{H}$ in the 1880s [45], there have been numerous investigations on the equilibria in the $\mathrm{CaO}-\mathrm{SiO}_{2}-\mathrm{H}_{2} \mathrm{O}$ system at room temperature. As Steinour noted in a 1947 review [46], it was evident that variations in solubility were present, but there was insufficient evidence and structural knowledge to determine if the variations were due to non-equilibrium conditions or differences in $\mathrm{C}-\mathrm{S}-\mathrm{H}$ structure.

In a later analysis of the data, Jennings [47] plotted the published solubility data available up to 1986 as $\mathrm{Ca}$ versus Si concentration. Since the Gibbs phase rule predicts a single degree of freedom when a solid phase is in equilibrium with an aqueous phase at fixed temperature and pressure (Section 2.1), plotting in this way should produce a smooth curve (i.e., the $\mathrm{Ca}$ and $\mathrm{Si}$ concentrations are linked). The analysis, in fact, identified two such solubility curves of differing $\mathrm{Si}$ concentration. The curve lower in $\mathrm{Si}$ concentration, curve A, was considered to be the metastable solubility curve for $\mathrm{C}-\mathrm{S}-\mathrm{H}(\mathrm{I})$. This conclusion was reached from XRD powder evidence and from the fact that most of the points on the curve were obtained from synthetic preparations made from $\mathrm{CaO}$ and $\mathrm{SiO}_{2}$ or from the double decomposition of sodium silicate with a Ca-salt in aqueous suspension. The curve with higher $\mathrm{Si}$ concentrations, curve B, was obtained solely from experiments conducted during the first several hours of $\mathrm{C}_{3} \mathrm{~S}$ hydration. Thermodynamic considerations [48] excluded the possibility that curve B represented a metastable solubility curve for $\mathrm{C}_{3} \mathrm{~S}$. It was thus presumed that curve $\mathrm{B}$ represented a metastable solubility curve for the initial product formed as a layer on the $\mathrm{C}_{3} \mathrm{~S}$ surface.

\footnotetext{
${ }^{\dagger}$ If viewed from the perspective of the liquid phase, this statement is equivalent to ensuring that the same solubility is obtained commencing from undersaturation and supersaturation with respect to $\mathrm{C}-\mathrm{S}-\mathrm{H}$ of a given $\mathrm{Ca} / \mathrm{Si}$ ratio.
} 
Although other interpretations of curve B have been offered [49], the product associated with this curve is not C-S-H(II), as was originally speculated [47] (but not firmly concluded), and may not even be $\mathrm{C}-\mathrm{S}-\mathrm{H}$ per se, that is, a structure based on composite layers of $\mathrm{Ca}-\mathrm{O}$ and dreierketten. ${ }^{29} \mathrm{Si}$ cross polarization (CP) NMR studies [50] show that the silicate anions are monomeric during the induction period, which suggests the presence of a superficially hydroxylated surface on $\mathrm{C}_{3} \mathrm{~S}$ [51].

2.3 Unsettled issues. Despite the numerous investigations on the $\mathrm{CaO}-\mathrm{SiO}_{2}-\mathrm{H}_{2} \mathrm{O}$ system at room temperature, important questions concerned with the equilibria of $\mathrm{C}-\mathrm{S}-\mathrm{H}$ remain unsettled. For example, most studies on hydrated $\mathrm{C}_{3} \mathrm{~S}$ (or $\square-\mathrm{C}_{2} \mathrm{~S}$ ) have measured solubility either at early ages or in dilute suspensions. It is generally assumed that the equilibrium of fully reacted $\mathrm{C}_{3} \mathrm{~S}$ paste and aqueous solution will occur at the intersection of the solubility curve of $\mathrm{CH}$ and curve A (i.e., the solubility curve of $\mathrm{C}-\mathrm{S}-\mathrm{H}(\mathrm{I})$ ), although it is known that the $\mathrm{C}-\mathrm{S}-\mathrm{H}$ gel produced in $\mathrm{C}_{3} \mathrm{~S}$ pastes is generally less crystalline and has a higher maximum $\mathrm{Ca} / \mathrm{Si}$ ratio of $\sim 1.8$. Moreover, the data from the only known study [52] to report both $\mathrm{Ca}$ and $\mathrm{Si}$ concentrations in solutions equilibrated with mature $\mathrm{C}_{3} \mathrm{~S}$ pastes do not show agreement with either curve A or B, and, in fact, points appear erratically scattered between the two curves, where it was originally believed that data (except for those from hydrating $\left[-\mathrm{C}_{2} \mathrm{~S}\right.$ ) arose from kinetic factors.

The maximum $\mathrm{Ca} / \mathrm{Si}$ ratio in $\mathrm{C}-\mathrm{S}-\mathrm{H}$ occurs when it is in equilibrium with an aqueous solution saturated with respect to $\mathrm{CH}$ (i.e., portlandite). However, reported values vary considerably, ranging from as low as 1.3 to as high as 2, those between 1.5 and 1.7-1.8 generally considered the most probably correct. Nonat and Lecoq [53] have attributed the higher values to a phase change in C-S-H at $20 \mathrm{mM}$ Ca. However, other than this suggestion or the possibility of non-equilibrium conditions [46], no explanation for the variability in $\mathrm{Ca} / \mathrm{Si}$ ratios at saturation in $\mathrm{CH}$ has been proposed.

There are no reported solubility data for jennite, $\mathrm{C}-\mathrm{S}-\mathrm{H}(\mathrm{II})$, or jennite-like $\mathrm{C}-\mathrm{S}-\mathrm{H}$. One could speculate that the scatter on curve $\mathrm{A}$ at high $\mathrm{Ca}$ concentration is due to jennite-like conformations, but without supporting evidence this suggestion cannot be made with confidence.

2.4. Current study. Given the uncertainties in the equilibria associated with $\mathrm{C}-\mathrm{S}-\mathrm{H}$, it appeared worthwhile to carefully analyze and contrast specimens derived from two distinct $\mathrm{C}-\mathrm{S}-\mathrm{H}$ preparations. One series was obtained from a nearly fully hydrated, hardened $\mathrm{C}_{3} \mathrm{~S}$ paste, the other from the double decomposition of $\mathrm{Ca}\left(\mathrm{NO}_{3}\right)_{2}$ and $\mathrm{Na}_{2} \mathrm{SiO}_{3}$. Solubility measurements, which were obtained from the decalcification of high $\mathrm{Ca} / \mathrm{Si}$ ratio solids and from the recalcification of low $\mathrm{Ca} / \mathrm{Si}$ solids, illustrate a family of solubility curves at high Ca concentration. ${ }^{29} \mathrm{Si}$ NMR and charge balance calculations show that these variations in solubility reflect systematic variations in $\mathrm{Ca} / \mathrm{Si}$ ratio, silicate structure, and $\mathrm{Ca}-\mathrm{OH}$ content. These findings have made it possible to more fully address existing uncertainties about the structure of $\mathrm{C}-\mathrm{S}-\mathrm{H}$ at high $\mathrm{Ca} / \mathrm{Si}$ ratios.

\section{Experimental}

3.1. Preparative methods. Tricalcium silicate pastes. $-\mathrm{C}_{3} \mathrm{~S}$ was prepared by firing a stoichiometric mixture of reagent grade $\mathrm{CaCO}_{3}$ and high-purity silica gel (EM Reagents, $\mathrm{HF}-254$ for TLC; $0.02 \% \mathrm{Cl}$, $0.02 \% \mathrm{Fe}$ ) at temperatures slightly exceeding $1420{ }^{\circ} \mathrm{C}$. As determined by XRD, complete reaction was obtained after three firings, each lasting at least 30 minutes. Prior to the second and third firings, samples were quickly cooled to room temperature, ground into a powder, and then pressed into discs to enhance homogeneity. The final product was passed through a $45-\square \mathrm{m}$ sieve. 
Hydrated $\mathrm{C}_{3} \mathrm{~S}$ pastes were prepared with deionized water at a water-to-solids ratio of 0.50. Samples were mixed by hand and cast in cylindrical polystyrene vials measuring $25 \mathrm{~mm}$ in diameter and $50 \mathrm{~mm}$ in height. After 3 days, the hardened pastes were demolded and stored in saturated solutions of $\mathrm{CH}$ in sealed polyethylene containers. Pastes were hydrated for approximately 8 months at $22 \pm 1^{\circ} \mathrm{C}$. Only trace amounts of anhydrous $\mathrm{C}_{3} \mathrm{~S}$ could be detected by XRD in the hydrated pastes, and the quantity of nonevaporable water retained after drying to the vapor pressure of water at $194 \mathrm{~K}$ (i.e., D-drying [54]) suggested that the pastes were over $95 \%$ hydrated. Solids derived from the $\mathrm{C}_{3} \mathrm{~S}$ pastes will be described as belonging to the $\mathrm{C}_{3} \mathrm{~S}$ group.

Double decomposition of calcium nitrate with sodium silicate.-A 0.050-mole quantity of reagent grade $\mathrm{Na}_{2} \mathrm{SiO}_{3} \cdot 5 \mathrm{H}_{2} \mathrm{O}$ was dissolved in $125 \mathrm{~mL}$ of carbon dioxide-free deionized water to which was added 0.075 moles of reagent grade $\mathrm{Ca}\left(\mathrm{NO}_{3}\right) \cdot 4 \mathrm{H}_{2} \mathrm{O}$ that was dissolved in $75 \mathrm{~mL}$ of carbon dioxide-free deionized water. Stirring was continued for one hour in a tightly sealed plastic container filled with nitrogen gas. The $\mathrm{C}-\mathrm{S}-\mathrm{H}$ precipitate was then washed with $2 \mathrm{~L}$ of a $20 \mathrm{mM} \mathrm{CH}$ solution on a Buchner funnel under a continuous stream of nitrogen. After the wash solution had passed through the solid, the sample was flushed with nitrogen and tightly sealed in a plastic container. The $\mathrm{C}-\mathrm{S}-\mathrm{H}$ precipitate had a $\mathrm{Ca} / \mathrm{Si}$ ratio of 1.40 with only trace amounts of residual alkali detectable by inductively coupled plasma atomic emission spectroscopy (ICP-AES). Solids derived from this preparation will be described as belonging to the double decomposition group.

Decalcification by concentrated ammonium nitrate solutions. - To facilitate determinations of the solubility of $\mathrm{C}-\mathrm{S}-\mathrm{H}$ at low $\mathrm{Ca} / \mathrm{Si}$ ratios, several of the samples in both groups were decalcified in $6 \mathrm{M}$ ammonium nitrate $\left(\mathrm{NH}_{4} \mathrm{NO}_{3}\right)$ solutions [55-57] prior to determinations of solubility. This technique results in a pure decalcification of cement pastes (i.e., there is negligible loss of $\mathrm{Si}$ ) and has been suggested as a preparation route for single-phase $\mathrm{C}-\mathrm{S}-\mathrm{H}$ samples from $\mathrm{C}_{3} \mathrm{~S}$ pastes [57].

$\mathrm{A}_{3} \mathrm{~S}$ paste was decalcified by immersing one $0.8-\mathrm{mm}$ thick disc in a stirred $100-\mathrm{mL}$ solution of $6 \mathrm{M}$ $\mathrm{NH}_{4} \mathrm{NO}_{3}$. Based on the weight of dry solid, the solution:solid weight ratio was $\sim 200$. The weight of the sample (measured in the saturated surface dry state) was monitored during leaching; using predetermined relationships between bulk $\mathrm{Ca} / \mathrm{Si}$ ratio and weight loss [57], the sample was removed from the $\mathrm{NH}_{4} \mathrm{NO}_{3}$ solution at a target weight loss and immediately immersed in $\sim 50 \mathrm{~mL}$ of deionized water to remove the residual $\mathrm{NH}_{4} \mathrm{NO}_{3}$ solution. As confirmed by pore fluid exchange calculations [58], approximately 10-15 min of gentle stirring in deionized water was sufficient for complete replacement of the heavier $\mathrm{NH}_{4} \mathrm{NO}_{3}$ solution $\left(\square \sim 1.13 \mathrm{~g} \mathrm{~cm}^{-3}\right)$ by water. A series of decalcified $\mathrm{C}_{3} \mathrm{~S}$ pastes with bulk $\mathrm{Ca} / \mathrm{Si}$ ratios of 0.11-2.04 were prepared in this way (Series 2, Table 1). Although gradients in composition were detected (e.g., a decalcified disc with a bulk $\mathrm{Ca} / \mathrm{Si}=0.83$ had $75 \%$ of its volume within $5 \%$ of the measured bulk composition [57]), the gradients are largely eliminated after exposing the solid to $\mathrm{CH}$ solution [57]; this recalcification procedure (section 3.2) will be exploited here to enhance homogeneity of the solids.

A single batch of $\mathrm{C}-\mathrm{S}-\mathrm{H}$ prepared by double decomposition was shaken in $6 \mathrm{M} \mathrm{NH}_{4} \mathrm{NO}_{3}$ solution for 5 min, rinsed for $10 \mathrm{~min}$ in deionized water, and then filtered on a Buchner funnel under a nitrogen stream. $\mathrm{The} \mathrm{Ca} / \mathrm{Si}$ ratio of the resulting leached solid was 0.55; XRD showed the presence of amorphous silica and $\mathrm{C}-\mathrm{S}-\mathrm{H}$.

3.2. Solubility measurements. The analytical concentrations of $\mathrm{Ca}$ and $\mathrm{Si}$ in equilibrium with solids of the $\mathrm{C}_{3} \mathrm{~S}$ and double decomposition groups were determined at $22 \pm 1{ }^{\circ} \mathrm{C}$. In all experiments, a given amount of solid, ranging from $0.01-0.8 \mathrm{~g}$, was equilibrated in $25 \mathrm{~mL}$ of deionized water or $\mathrm{CH}$ solution; the corresponding solution:solid ratios ranged from $\sim 4000$ to 50. To minimize carbonation, samples were 
crushed under nitrogen, the deionized water was freshly boiled, and the $\mathrm{CaO}$ used in the $\mathrm{CH}$ solutions was prepared from freshly decomposed reagent grade $\mathrm{CaCO}_{3}$. Samples were continuously tumbled end-overend in 30-mL Nalgene centrifuge vials that were sealed with screw caps, fitted with rubber gaskets. After a shaking period lasting up to 6 weeks (see below), the solutions were filtered under flowing nitrogen through 0.2- $\square \mathrm{m}$ filters; the resulting filtrates were immediately acidified with $\mathrm{HCl}$ and then measured for $\mathrm{Ca}, \mathrm{Si}$, and (in some samples) $\mathrm{Na}$ by ICP-AES.

Equilibration periods for the $C_{3} S$ group ranged from 2-6 weeks (with an average of 4) while those for the double decomposition group ranged from 3 days -6 weeks (with an average of 2 weeks). Solubility values were generally in agreement within each group, but in the few cases where divergent results were obtained, continued shaking of the experiment nearly always produced results in agreement with the rest of the group. While this process only yields circumstantial evidence that a steady state was achieved, it was preferred to collecting intermittent measurements on the same sample, which would have increased the likelihood for carbonation.

The $\mathrm{C}_{3} \mathrm{~S}$ group (Series 1, 2, and $3^{*}$ ) and the double decomposition group (Series $4,5^{*}$, and $6^{*}$ ) each contained 3 different series (see Table 1). These series are divided into those in which equilibrium was approached through the decalcification of a high $\mathrm{Ca} / \mathrm{Si}$ solid (Series 1, 2, and 4) and those in which equilibrium was approached through the recalcification of a low $\mathrm{Ca} / \mathrm{Si}$ ratio solid (Series $3^{*}, 5^{*}$, and $6^{*}$ ); the asterisks in the latter group are used to distinguish the two routes to equilibrium. Decalcified samples were either leached (and equilibrated) in water or were leached in $6 \mathrm{M} \mathrm{NH}_{4} \mathrm{NO}_{3}$ solution, rinsed, and then equilibrated in water. Recalcified samples were water- or $\mathrm{NH}_{4} \mathrm{NO}_{3}$-leached solids that were equilibrated in $\mathrm{CH}$ solution, the initial concentration of which depended on the target $\mathrm{Ca} / \mathrm{Si}$ ratio of the solid; for example, in some cases where the target $\mathrm{Ca} / \mathrm{Si}$ ratio was high, the solid was initially exposed to a supersaturated solution of $\mathrm{CH}$. The $\mathrm{CaO}$ used to prepare the $\mathrm{CH}$ solutions was passed through a $75-\square \mathrm{m}$ mesh sieve before adding to decarbonated, deionized water. Further details on the recalcification procedure can be found elsewhere [57].

For most determinations of $\mathrm{Ca} / \mathrm{Si}$ ratio, the solid was decomposed with $\mathrm{LiBO}_{3}$ at $1000{ }^{\circ} \mathrm{C}$ to form a glass soluble in weakly acidic solution, which was then analyzed for $\mathrm{Ca}$ and Si by ICP-AES [59]. In the several cases where the $\mathrm{Ca} / \mathrm{Si}$ ratio was not directly determined, values were calculated from differences in the initial and final concentrations of $\mathrm{Ca}$ and $\mathrm{Si}$ in solution; measured and calculated values of $\mathrm{Ca} / \mathrm{Si}$ ratio generally agreed to within $2 \%$.

The $\mathrm{pH}$ values were determined on unfiltered portions of the equilibrated solution using a glass electrode.

3.3. ${ }^{29}$ Si magic-angle spinning (MAS) NMR. The ${ }^{29}$ Si MAS NMR spectra were collected on a Varian VXR300 (7 T) spectrometer operating with a magnetic field of $59.578 \mathrm{MHz}$ and a spinning rate of $4 \mathrm{kHz}$. A 5-mm zirconia rotor with Aurum caps was used for all experiments. Samples were collected for 800 scans, each consisting of a single pulse of width $4.7 \square \mathrm{s}$ followed by a delay of $10 \mathrm{~s}$. Longer delay times of up to $100 \mathrm{~s}$ were also tried, but the improvements in the quality of the scans were considered insufficient to warrant the longer collection times. Chemical shifts are reported relative to tetramethylsilane (TMS), using tetrakis(trimethylsilyl)silane, $\mathrm{Si}\left(\mathrm{Si}\left(\mathrm{CH}_{3}\right)_{3}\right)_{4}$, as an external standard.

Relative intensities of the $\mathrm{Q}^{\mathrm{i}}{ }^{29} \mathrm{Si}$ peaks were measured through deconvolutions of the spectra by commercial NMR spectroscopy analysis software. It is easily shown that, if $\mathrm{C}-\mathrm{S}-\mathrm{H}$ contains no $\mathrm{Q}^{3}$, the mean chain length is given by $2\left(1+\mathrm{Q}^{2} / \mathrm{Q}^{1}\right)$. As will be discussed, the shoulder at $-83 \mathrm{ppm}$ on the $\mathrm{Q}^{2}$ peak was assigned as an integral part of the main $\mathrm{Q}^{2}$ peak at $-85 \mathrm{ppm}$. 
The samples in series $\mathrm{N}$ (Table 2) consisted of $\mathrm{C}_{3} \mathrm{~S}$ pastes decalcified in $\mathrm{NH}_{4} \mathrm{NO}_{3}$ solutions; these samples were rinsed in deionized water, lightly crushed, and briefly dried under nitrogen before analysis by ${ }^{29} \mathrm{Si} \mathrm{NMR}$. Several samples from Series $3^{*}$ of the $\mathrm{C}_{3} \mathrm{~S}$ group (see Table 1) were also analyzed. Samples in the double decomposition group were selected from Series $4,5^{*}$, and $6^{*}$ (Table 1). The higher water contents of these samples necessitated preliminary drying for approximately 20 min under the vacuum of a rotary pump. This procedure was necessary to prevent sticking and subsequent spinning problems in the rotor.

3.4. XRD. XRD powder scans of several samples collected from the solubility experiments were acquired with a Rigaku X-ray diffractometer with CuK $\square$ radiation operating at $40 \mathrm{kV}$ and $20 \mathrm{~mA}$. Scans were collected at $0.75^{\circ} 2 \square \cdot \mathrm{min}^{-1}$ over the range $5^{\circ}-60^{\circ} 2 \square$.

\section{Results and Discussion}

A summary of the phase equilibrium results for the $\mathrm{C}_{3} \mathrm{~S}$ and double decomposition groups is given in Tables 2 and 3, respectively.

4.1. Solubility. Figure 2 shows the $\mathrm{Ca}$ and $\mathrm{Si}$ concentrations in aqueous solution after shaking with samples of the $\mathrm{C}_{3} \mathrm{~S}$ and double decomposition groups for generally 4 and 2 weeks, respectively; shaking for 6 weeks produced results in agreement with those shown, suggesting that at least a near steady-state had been achieved. Moreover, the concentrations in both groups were obtained from the decalcification of a high $\mathrm{Ca} / \mathrm{Si}$ ratio solid and the recalcification of a low $\mathrm{Ca} / \mathrm{Si}$ ratio solid. With the thermodynamic considerations discussed in Section 2.1, the agreement from both directions suggests the occurrence of a metastable equilibrium between $\mathrm{C}-\mathrm{S}-\mathrm{H}$ and aqueous solution.

Figure 2 shows that the equilibrium concentrations for both groups of preparations lie near curve A (i.e., the solubility curve for $\mathrm{C}-\mathrm{S}-\mathrm{H}(\mathrm{I})$ ) at low Ca concentrations, but depart from it at high concentrations onto two apparently parallel solubility curves. The concentrations for the $\mathrm{C}_{3} \mathrm{~S}$ group fall on the curve higher in Si concentration, curve $\mathrm{C}$, which departs from curve $\mathrm{A}$ when the Ca concentration is $\sim 4 \mathrm{mM} \mathrm{Ca}$ and when the $\mathrm{Ca} / \mathrm{Si}$ ratio of the solid is $\sim 1.2$; at $\mathrm{CH}$ saturation, an essentially unleached $\mathrm{C}_{3} \mathrm{~S}$ paste (with $\mathrm{Ca} / \mathrm{Si}=3.00$ ) equilibrated at the intersection of the $\mathrm{CH}$ solubility curve and curve $\mathrm{C}$, not curve $\mathrm{A}$ as is generally presumed. The concentrations of the double decomposition group make a similar departure from curve A onto $\mathrm{C}^{\prime \prime}$, but at a slightly higher $\mathrm{Ca}$ concentration and $\mathrm{Ca} / \mathrm{Si}$ ratio of $\sim 8 \mathrm{mM} \mathrm{Ca}$ and 1.3 , respectively.

As discussed in Section 5, it is believed that the departures from curve A onto $\mathrm{C}$ or $\mathrm{C}$ " are caused by the introduction of $\mathrm{Ca}-\mathrm{OH}$ groups into $\mathrm{C}-\mathrm{S}-\mathrm{H}$. It will be further argued that that these changes in solubility signify a departure from a purely tobermorite-like structure, represented by curve A, to structures that include jennite-like characteristics in $\mathrm{C}$, and to a lesser extent in C".

Contamination. - Although the higher than expected $\mathrm{Si}$ concentrations on curves $\mathrm{C}$ or $\mathrm{C}$ " could be construed as a result of systemic bias introduced by contamination, it does not appear likely. The sources of $\mathrm{CaO}$ and $\mathrm{SiO}_{2}$ used to synthesize the $\mathrm{C}_{3} \mathrm{~S}$ were from essentially pure reagents, and utmost care was taken during all stages of the solubility experiments to minimize carbonation. Moreover, the agreement shown by recalcified $\mathrm{C}-\mathrm{S}-\mathrm{H}$ solids that were leached in $\mathrm{NH}_{4} \mathrm{NO}_{3}$ (Series $5^{*}$ ) or in water (Series $6^{*}$ ) suggests an insignificant contamination by $\mathrm{NH}_{4}{ }^{+}$and $\mathrm{NO}_{3}{ }^{-}$ions.

The most probable source of contamination would be from residual $\mathrm{Na}$ in samples of the double decomposition group. However, in the several samples examined, solution concentrations were generally 
less than $0.02 \mathrm{mM} \mathrm{Na}$, and the $\mathrm{Na} / \mathrm{Si}$ ratio of the solids were $\sim 0.01$, near the detection limit of ICP-AES. Contamination was thus insignificant. Moreover, the trends in Figure 2 show that, at a given $\mathrm{Ca} / \mathrm{Si}$ ratio, samples of the double decomposition group have higher $\mathrm{Ca}$ and lower $\mathrm{Si}$ concentrations in the aqueous phase than those of the $\mathrm{C}_{3} \mathrm{~S}$ group. If contamination by alkali were the cause of the differences between the two groups, these trends would be reversed $[60,61]$.

Effect of particle size.-It also appears unlikely that the variations in solubility in Figure 2 are due to variations in particle size. Recent small-angle neutron scattering (SANS) results [62] show that the specific surface areas of decalcified/recalcfied $\mathrm{C}-\mathrm{S}-\mathrm{H}$ solids produced from $\mathrm{C}_{3} \mathrm{~S}$ pastes and from double decomposition all follow the same inverse, linear relationship between $\mathrm{Ca} / \mathrm{Si}$ ratio and specific surface area; the particle sizes of solids equilibrated on $\mathrm{C}$ and $\mathrm{C}$ " are thus similar. Comparable specific surface areas have also been found between ill-crystallized $\mathrm{C}-\mathrm{S}-\mathrm{H}$ solids prepared from suspensions of $\mathrm{CaO}$ and $\mathrm{SiO}_{2}$ and from $\mathrm{C}_{3} \mathrm{~S}$ and $\left[-\mathrm{C}_{2} \mathrm{~S}\right.$ pastes [23].

Stability. - The C-S-H phases represented by curves $\mathrm{C}$ and $\mathrm{C}$ " appear to be relatively stable to large fluctuations in composition. For example, the same invariant point (i.e., the 3-phase equilibrium between aqueous solution, $\mathrm{C}-\mathrm{S}-\mathrm{H}$ and $\mathrm{CH}$ ) was reached at $[\mathrm{Ca}]=20.6 \mathrm{mM},[\mathrm{Si}]=42 \square \mathrm{M}$ when equilibrating a $\mathrm{C}_{3} \mathrm{~S}$ paste specimen before leaching (sample 1a) and after the combined process of decalcification to $\mathrm{Ca} / \mathrm{Si}=1.09$ and recalcification to $\mathrm{Ca} / \mathrm{Si}=1.87$ (sample $3 \mathrm{~g}^{*}$ ); the $\mathrm{Ca} / \mathrm{Si}$ ratio of 1.09 corresponds to $\mathrm{C}-\mathrm{S}-\mathrm{H}$ equilibrated on curve $\mathrm{A}$. The reattainment of the invariant point after such a large fluctuation in composition suggests that the $\mathrm{C}-\mathrm{S}-\mathrm{H}$ associated with curve $\mathrm{C}$ is a relatively stable (but still metastable) phase at least on a time scale of several weeks (the duration of a typical experiment); if this were not true, that is, if the $\mathrm{C}-\mathrm{S}-\mathrm{H}$ phase on curve $\mathrm{C}$ were truly unstable, then the decalcification/recalcification procedure as experienced by sample $3 \mathrm{~g}^{*}$ would be expected to produce a phase of lower free energy, and hence, of different solubility. A similar argument can be given for solids of the double decomposition group that equilibrate reversibly on curve $\mathrm{C}^{\prime \prime}$. It thus appears justified in referring to the $\mathrm{C}-\mathrm{S}-\mathrm{H}$ solids equilibrated on curves $C$ and $C^{\prime \prime}$ as metastable phases. In ensuing sections, it is also shown that the structures of the phases at a given composition are different, thereby further illustrating that these phases are distinct.

4.2. Ca concentration versus $\mathbf{C a} / \mathrm{Si}$ of the solid. Figure 3 plots the $\mathrm{Ca}$ concentration in aqueous solution versus the $\mathrm{Ca} / \mathrm{Si}$ ratio of the solid with which it is in equilibrium. Of central interest here is the two-phase $\mathrm{C}-\mathrm{S}-\mathrm{H} /$ aqueous solution region between $\sim 1.2$ to $20.6 \mathrm{mM} \mathrm{Ca}$. The $\mathrm{Ca} / \mathrm{Si}$ ratios of the $\mathrm{C}_{3} \mathrm{~S}$ and the double decomposition groups both increase with $\mathrm{Ca}$ concentration, as expected, but two different curves are suggested from the data. Ignoring samples $1 \mathrm{c}-1 \mathrm{~g}$ (which are only believed to be in partial equilibrium as discussed below), the $\mathrm{Ca} / \mathrm{Si}$ ratios of the $\mathrm{C}_{3} \mathrm{~S}$ group follow the upper curve, which leads to maximum $\mathrm{Ca} / \mathrm{Si}$ ratio of $\sim 1.8$ at $\mathrm{CH}$ saturation; this value agrees with EDX [26-31] and indirect [24,25] measurements on $\mathrm{C}_{3} \mathrm{~S}$ pastes. The $\mathrm{Ca} / \mathrm{Si}$ ratios of the double decomposition group follow the lower curve, which leads to a maximum $\mathrm{Ca} / \mathrm{Si}$ ratio of $\sim 1.5$; this value agrees with other equilibrium studies using double decomposition (Section 5.4). As discussed in Section 5.4, the discrepancy between the 1.5 and 1.8 values appears to be associated with variations in $\mathrm{Ca}-\mathrm{OH}$ content in $\mathrm{C}-\mathrm{S}-\mathrm{H}$.

Homogeneity. - Under ideal equilibrium conditions, the dissolution of a $\mathrm{C}_{3} \mathrm{~S}$ paste in water will entirely remove $\mathrm{CH}$ before $\mathrm{C}-\mathrm{S}-\mathrm{H}$ begins to decalcify. However, dissolution proceeds by the propagation of a reactive front [55], so in samples of finite thickness, the $\mathrm{C}-\mathrm{S}-\mathrm{H}$ at the surface of the specimen will inevitably decalcify before $\mathrm{CH}$ in the inner regions of the body have been accessed. Since XRD data (Section 4.3) showed that samples $1 \mathrm{c}-1 \mathrm{~g}$ contained $\mathrm{CH}$, the above reasoning explains the higher than 
expected $\mathrm{Ca} / \mathrm{Si}$ ratios for samples $1 \mathrm{c}-1 \mathrm{~g}$ (dashed circles in Figure 3); these values were thus excluded from the trend line drawn for the $\mathrm{C}_{3} \mathrm{~S}$ group in Figure 3. The solubility of samples $1 \mathrm{c}-1 \mathrm{~g}$, however, may still reflect a partial equilibrium condition as discussed below.

An important phenomenon exploited here is the finding [57] that the compositional gradients induced by leaching are largely eliminated after recalcification in $\mathrm{CH}$ solution; this is illustrated in the EDX results of Figure 4, which shows a fairly constant $\mathrm{Ca} / \mathrm{Si}$ ratio across the 0.8 -mm thickness of a paste that had been recalcified from a bulk $\mathrm{Ca} / \mathrm{Si}$ of 0.83 to a value of 1.31 . The compositional homogeneity of recalcified solids suggested by this result indicates that the entirety of a recalcified specimen ultimately reaches equilibrium with aqueous solution; this, in turn, supports the validity of curves $\mathrm{C}$ and $\mathrm{C}$ ", since they were mainly established from recalcification experiments. That the $\mathrm{Ca}$ and $\mathrm{Si}$ concentrations in solution of samples $1 \mathrm{c}-1 \mathrm{~g}$ of the $\mathrm{C}_{3} \mathrm{~S}$ group agree with those of recalcified samples (Series $3^{*}$ ) appears to suggest that the surface regions of the leached particles were in equilibrium, while the inner regions containing $\mathrm{CH}$ were not. This inhomogeneity could possibly have been eliminated or reduced by finer grinding.

4.3. XRD. Figure 5 shows selected powder XRD scans from the $\mathrm{C}_{3} \mathrm{~S}$ and double decomposition group. The results indicate a fairly low degree of order in all samples, as the only relatively sharp peaks are those at $0.304,0.279$ and $0.182 \mathrm{~nm}$. Since all forms of C-S-H that are sufficiently crystalline give peaks in these regions, they are of no diagnostic value to determine the structural likeness of $\mathrm{C}-\mathrm{S}-\mathrm{H}$ to $1.4-\mathrm{nm}$ tobermorite or jennite. No clear indications of basal reflections were observed, suggesting little more than two-dimensional order. Except for the removal of $\mathrm{CH}$ from $\mathrm{C}_{3} \mathrm{~S}$ pastes, the weak peak at $0.166 \mathrm{~nm}$ (prominent at lower $\mathrm{Ca} / \mathrm{Si}$ ratios), and the presence of silica gel (marked by a broad band at $22.5^{\circ} 2 \square$ ) at $\mathrm{Ca} / \mathrm{Si}$ ratios less than about 0.6-0.7, there does not appear to be a significant change in the XRD patterns with preparation or $\mathrm{Ca} / \mathrm{Si}$ ratio. Differences in crystallinity thus cannot solely account for the variations in solubility (Figure 2) and $\mathrm{Ca} / \mathrm{Si}$ ratio (Figure 3).

4.4. ${ }^{29} \mathrm{Si}$ NMR. Table 4 summarizes the ${ }^{29} \mathrm{Si}$ NMR results, and Figure 6 shows a selection of the spectra. Nearly all samples show peaks near -79 and $-85 \mathrm{ppm}$, attributable to $\mathrm{Q}^{1}$ and $\mathrm{Q}^{2}$ Si sites, respectively. $\mathrm{Q}^{1}$ sites can be found on isolated pairs of tetrahedra (i.e., dimers) or on the ends of silicate chains; $\mathrm{Q}^{2}$ sites are found in the middle of the chains. The absence of $Q^{3}$ (cross-linking) sites at $-94 \mathrm{ppm}$ indicates the presence of single dreierketten. The hydroxylated $\mathrm{Q}^{3}(\mathrm{OH})(-101 \mathrm{ppm})[63]$ and $\mathrm{Q}^{4}$ sites $(-110 \mathrm{ppm})$ observed in sample $\mathrm{N} 5(\mathrm{Ca} / \mathrm{Si}=0.17)$ can be assigned to silica gel, in agreement with the XRD evidence. The lack of detectable amounts of $\mathrm{Q}^{0}$ in the samples prepared from $\mathrm{C}_{3} \mathrm{~S}$ is a good indication that these samples were nearly fully reacted.

In some of the spectra, the $\mathrm{Q}^{2}$ peak has a shoulder near $-83 \mathrm{ppm}$. This shoulder has been observed by a number of investigators [3,4,19,31,64-67], but its assignment is still uncertain. It is generally assumed that the shoulder is produced by a subset of the $\mathrm{Q}^{2} \mathrm{Si}$, and it is likely to represent at least some of those present as bridging tetrahedra [4,67]. The current results are consistent with (but not proof of) this last hypothesis, as the shoulder becomes increasingly prominent as the $\mathrm{Ca} / \mathrm{Si}$ ratio decreases. Distinctions between different types of $\mathrm{Q}^{2}$ sites, however, are not relevant in the present context, and for the purposes of calculating the mean chain length, it is assumed that the shoulder is an integral part of the main $\mathrm{Q}^{2}$ peak near $-85 \mathrm{ppm}$.

Mean silicate chain length.-Figure 7 shows the mean silicate chain lengths for the $\mathrm{C}_{3} \mathrm{~S}$ and double decomposition groups plotted as a function of $\mathrm{Ca} / \mathrm{Si}$ ratio. In both cases, the mean chain length increases with decreasing $\mathrm{Ca} / \mathrm{Si}$ ratio, in agreement with previous ${ }^{29} \mathrm{Si}$ NMR studies $[3,4,16-20]$. However, for 
$\mathrm{Ca} / \mathrm{Si}$ ratios above 1, there is a small but significant difference between the two preparations, as the mean chain lengths of the samples from the $\mathrm{C}_{3} \mathrm{~S}$ group are consistently higher than those from the double decomposition group. This finding, central to the hypothesis presented in Sections 5.2 and 5.3, indicates that variations in mean chain length in $\mathrm{C}-\mathrm{S}-\mathrm{H}$ are possible for a given $\mathrm{Ca} / \mathrm{Si}$ ratio.

Indirect evidence for $\mathrm{Ca}-\mathrm{OH}$ in $\mathrm{C}-\mathrm{S}-\mathrm{H}$. $-\mathrm{As}$ also noted in $\mathrm{C}-\mathrm{S}-\mathrm{H}$ of other studies $[3,12,19]$, the mean silicate chain lengths of samples from the $\mathrm{C}_{3} \mathrm{~S}$ and double decomposition groups show relatively little change above $\mathrm{Ca} / \mathrm{Si}$ ratios of 1.2-1.3. The constancy of the mean chain length has been interpreted by $\mathrm{Yu}$ et al. [12] as evidence that the predominant cause of variation in $\mathrm{Ca} / \mathrm{Si}$ ratios above $\sim 1.3$ is the chargebalancing substitution of $\mathrm{OH}$ for entire silicate chain segments; this substitution creates $\mathrm{Ca}-\mathrm{OH}$ groups (i.e., $\mathrm{Ca}$ balanced by $\mathrm{OH}$ but not by $\mathrm{Si}$ anions), which the authors equated with the formation of jennite or jennite-like environments in $\mathrm{C}-\mathrm{S}-\mathrm{H}$. Below $\mathrm{Ca} / \mathrm{Si}$ ratios of $\sim 1.3$, they considered the dominant structural mechanism for increasing $\mathrm{Ca} / \mathrm{Si}$ ratio was depolymerization of silicate chains due to the substitution of interlayer calcium (i.e., $\mathrm{Ca}$ balanced by $\mathrm{Si}$ anions) for bridging tetrahedra and protons on $\mathrm{Si}-\mathrm{OH}$.

Since the points of intersection of curve A with curves $\mathrm{C}$ and $\mathrm{C}$ " occur near 1.2 and 1.3, respectively, the above interpretations suggest a connection between silicate polymerization and solubility. The hypothesis, developed in Sections 5.2 and 5.3, is that the point at which the concentrations depart from A onto $\mathrm{C}$ or $\mathrm{C}$ " marks the point where a shift in the mode of silicate polymerization and in the mode of $\mathrm{Ca}$ incorporation in $\mathrm{C}-\mathrm{S}-\mathrm{H}$ occurs. Curve $\mathrm{A}$ is believed to represent $\mathrm{C}-\mathrm{S}-\mathrm{H}$ solids in which the mean chain length varies from changes in the content of interlayer $\mathrm{Ca}$, while curves $\mathrm{C}$ and $\mathrm{C}$ " represent $\mathrm{C}-\mathrm{S}-\mathrm{H}$ solids in which the mean chain length remains constant as changes in the content of $\mathrm{Ca}-\mathrm{OH}$ occur.

Reversibility of silicate polymerization.-Figure 7 shows that there is agreement in mean chain length for solids approaching equilibrium through the decalcification of a high $\mathrm{Ca} / \mathrm{Si}$ ratio solid and through the recalcification of a low $\mathrm{Ca} / \mathrm{Si}$ ratio solid; the process of silicate polymerization in $\mathrm{C}-\mathrm{S}-\mathrm{H}$ is thus reversible. This finding emphasizes the predominant role $\mathrm{Ca}$ cations have on the configuration of the silicate anions in $\mathrm{C}-\mathrm{S}-\mathrm{H}$. In fact, the predominant role of the cation in any silicate structure is a wellestablished phenomenon $[68,69]$. For example, if a small cation such as $\mathrm{Mg}^{2+}$ is the sole metal cation, or at least the one that is the more important in determining the silicate structure, configurations based on zweierketten (i.e., silicate chains with a 2-unit repeat) can form. However, when the larger $\mathrm{Ca}^{2+}$ is the determining cation, as is the case in $\mathrm{C}-\mathrm{S}-\mathrm{H}$, quite different silicate structures are produced, some of which are based on dreierketten (e.g., tobermorite, wollastonite, xonolite).

Changes in chemical shift of $Q^{l}$ and $Q^{2}$ Si sites. - As seen in Figure 8 for samples of the $\mathrm{C}_{3} \mathrm{~S}$ group, the chemical shifts of the $\mathrm{Q}^{1}$ and $\mathrm{Q}^{2} \mathrm{Si}$ sites shift to increasingly negative (i.e., upfield) values as the $\mathrm{Ca} / \mathrm{Si}$ ratio of $\mathrm{C}-\mathrm{S}-\mathrm{H}$ decreases. This trend was also seen in the samples of the double decomposition group, although with slightly more scatter. Other ${ }^{29} \mathrm{Si}$ NMR data $[4,70,71]$ on $\mathrm{C}-\mathrm{S}-\mathrm{H}$ preparations from lime and silica show the same trend, but it was only noted by Klur et al. [4]. These observations suggest a systematic change with $\mathrm{Ca} / \mathrm{Si}$ ratio in the local structural environment of $\mathrm{Si}$ in $\mathrm{C}-\mathrm{S}-\mathrm{H}$. More research is required to explain this structural change.

4.5. Ca/Si of the solid versus pH. Figure 9 shows the measured (points) and computed (lines) $\mathrm{pH}$ values of the aqueous solution plotted versus the $\mathrm{Ca} / \mathrm{Si}$ ratio of the solid with which the solution is in equilibrium. Computed $\mathrm{pH}$ values were calculated by balancing the charge of the aqueous species (e.g., $\mathrm{CaOH}^{+}, \mathrm{H}_{2} \mathrm{SiO}_{4}{ }^{2-}$ ), the distribution of which was calculated from the measured $\mathrm{Ca}$ and $\mathrm{Si}$ concentrations using a geochemical modeling program, PHREEQC [72]; the Debye-Huckel or the Davies equation was used to account for non-ideal behavior, and the ionic association constants used here are listed elsewhere 
[73]. For the $\mathrm{pH}$ values above 11.5 (the range with which we are most concerned), all values (except for several belonging to group 4) were generally within \pm 0.05 of the computed values, thereby giving a selfconsistent check for the analyses of the solutions. The outlying values associated with samples $4 \mathrm{c}^{*}, 4 \mathrm{~d}, 4 \mathrm{e}$, $4 \mathrm{~g}$, and $4 \mathrm{i}$ of the double decomposition group (Table 3 ) appear to be due to a systematic error since all are consistently below the computed value by $\sim 0.25$.

The computed curves in Figure 9 expect that, at a given $\mathrm{Ca} / \mathrm{Si}$ ratio above $\sim 1.3$, the $\mathrm{pH}$ associated with solids equilibrated on curve $C^{\prime \prime}$ (double decomposition) are higher than those on curve $C\left(\mathrm{C}_{3} \mathrm{~S}\right.$ paste). Although there is uncertainty regarding several of the values of the double decomposition group as noted above, this conclusion is supported by samples $4 \mathrm{a}^{*}$ and $6 \mathrm{a}^{*}$ of the double decomposition group, which show the highest $\mathrm{pH}$ values in for $\mathrm{Ca} / \mathrm{Si}$ ratios between 1.3-1.5. Together with the differences illustrated in solubility, $\mathrm{Ca} / \mathrm{Si}$ ratio, and mean chain length, the difference in $\mathrm{pH}$ at a given $\mathrm{Ca} / \mathrm{Si}$ ratio between solids of the $\mathrm{C}_{3} \mathrm{~S}$ and double decomposition groups is further evidence that these solids have distinct structures.

\section{Relationships between solubility and structure}

5.1. Published solubility. The validity of curves $C$ and $C "$ is supported by their reversibility; that is, except in the few cases where only partial equilibrium was achieved, the same solubility, solid $\mathrm{Ca} / \mathrm{Si}$ ratio, and mean silicate chain length were obtained when approaching equilibrium from the decalcification of a high $\mathrm{Ca} / \mathrm{Si}$ ratio solid and from the recalcification of a low $\mathrm{Ca} / \mathrm{Si}$ ratio solid. Since the $\mathrm{C}-\mathrm{S}-\mathrm{H}$ solids that equilibrate on these curves have different structures at a given $\mathrm{Ca} / \mathrm{Si}$ ratio, and since neither solid readily transforms into the other (at least on a time scale of several weeks to probably several months), these findings suggest that the $\mathrm{C}-\mathrm{S}-\mathrm{H}$ solids associated with curves $\mathrm{C}$ and $\mathrm{C}$ " are distinct metastable phases. As signified by its association with a curve (rather than, for example, a point), each of these phases at equilibrium has one degree of freedom in composition (Section 2.1). Since other metastable phases and thus additional solubility curves would be reasonably expected from a material such as $\mathrm{C}-\mathrm{S}-\mathrm{H}$, a reevaluation of the published solubility data in the $\mathrm{CaO}-\mathrm{SiO}_{2}-\mathrm{H}_{2} \mathrm{O}$ system at room temperature was undertaken.

Figure 10 plots the published data from several well-known investigations, most of which were selected for the completeness of their data sets. Some of the points at high Ca concentrations were not plotted in an earlier depiction [47] of the solubility phase diagram either because data were considered erratic (such as those of Kalousek [74]) or were difficult to obtain, since they were plotted rather than tabulated [21,75]; for the latter cases, "new" data points shown in Figure 10 were obtained from image analysis of digitally scanned figures. These points support curves $\mathrm{C}$ and $\mathrm{C}$ " and provide evidence for at least one other curve, curve $\mathrm{C}^{\prime}$, which is situated between them. The $\mathrm{Ca} / \mathrm{Si}$ ratios of the solids equilibrated at, or nearest to, the intersections of curves $\mathrm{C}, \mathrm{C}^{\prime}$, and $\mathrm{C}^{\prime \prime}$ with curve $\mathrm{A}$ and with the solubility curve of $\mathrm{CH}$ are also noted on Figure 10. Since it is probable that additional curves exist (although not likely outside the boundaries of those drawn; see Section 5.3), the labeling scheme used here is solely for the purposes of identification; an alternative nomenclature may therefore be necessary when a more complete data set is obtained. Relevant details for individual data sets in Figure 10 are given below.

Curve C.-This is drawn from the data of the present investigation (mature $\mathrm{C}_{3} \mathrm{~S}$ paste, $22{ }^{\circ} \mathrm{C}$ ) and from nearly all of those obtained by Kalousek [74] (lime-silica, $25^{\circ} \mathrm{C}$ ). Two points from the latter study [74], at 4.2 and $5.8 \mathrm{mM} \mathrm{Ca}$, appear inconsistent with the rest, since they lie on curve A rather than C. Samples 21,23 , and 26 in the same study [74] were excluded because they gave points lying substantially above 
curve B. One data point out of the four obtained by Greenberg and Chang [52] for mature $\mathrm{C}_{3} \mathrm{~S}$ paste at 25 ${ }^{\circ} \mathrm{C}$ also lies on this curve. $\mathrm{C}-\mathrm{S}-\mathrm{H}$ equilibrated at the intersection of curve $\mathrm{C}$ with $\mathrm{A}$ occurs at a $\mathrm{Ca} / \mathrm{Si}$ ratio near 1.2.

Curve $C^{\prime}$. - This is drawn from the data of Flint and Wells [75] (lime-silica, $30^{\circ} \mathrm{C}$ ). The nearest point to the intersection with $\mathrm{A}$ is associated with $\mathrm{C}-\mathrm{S}-\mathrm{H}$ of $\mathrm{Ca} / \mathrm{Si}$ equal to 1.25.

Curve $C^{\prime \prime}$. - This is drawn from the data of Greenberg and Chang [52] (lime-silica, prepared at $50{ }^{\circ} \mathrm{C}$, equilibrated at $25^{\circ} \mathrm{C}$ ) and that of Roller and Ervin [76] (double decomposition, $30{ }^{\circ} \mathrm{C}$ ). The remaining 3 points from Greenberg and Chang [52] for mature $\mathrm{C}_{3} \mathrm{~S}$ paste lie on curve $\mathrm{C}^{\prime \prime}$ or between it and curve $\mathrm{A}$. $\mathrm{C}-\mathrm{S}-\mathrm{H}$ samples equilibrated at the intersection of curve $\mathrm{C}$ " with $\mathrm{A}$ have $\mathrm{Ca} / \mathrm{Si}$ ratios near 1.3.

Curve A.-This is drawn from the data of Brown et al. [77] $\left(\mathrm{C}_{3} \mathrm{~S}, 24{ }^{\circ} \mathrm{C}\right.$ ), Taylor [21] (double decomposition, lime-silica, $17{ }^{\circ} \mathrm{C}$ ), and Fujii and Kondo [78] (double decomposition, prepared at $20{ }^{\circ} \mathrm{C}$, equilibrated at $30{ }^{\circ} \mathrm{C}$ ). In the data of Brown et al. [77], $\mathrm{C}_{3} \mathrm{~S}$ was hydrated using water:solid ratios of $0.7-20$, and ages of $30 \mathrm{~s}-4 \mathrm{~h}$. With increasing age in this range, the concentrations moved along curve A from low $\mathrm{Ca}$ concentration to supersaturation in $\mathrm{CH}$ at $\sim 30 \mathrm{mM} \mathrm{Ca}$, and then back to saturation at $\sim 21$ $\mathrm{mM} \mathrm{Ca}^{\dagger}$. The data from Fujii and Kondo [78] were taken from the authors' Figure 2 rather than from the values listed in their table on p. 649 of ref. [78] or in Table II of ref.[80], since these tabulated values were based on a thermodynamic fit, which gives misleadingly high $\mathrm{Ca} / \mathrm{Si}$ ratios for $\mathrm{C}-\mathrm{S}-\mathrm{H}$. $\mathrm{Ca} / \mathrm{Si}$ ratios of $\mathrm{C}-\mathrm{S}-\mathrm{H}$ samples equilibrated at the intersection of curve A with the solubility curve for $\mathrm{CH}$ are near 1.5 .

Other possible curves. - The data of Grutzeck et al. [17] (lime-silica, $25{ }^{\circ} \mathrm{C}$ ) suggest the possibility of a curve higher in Si concentrations than curve $\mathrm{C}$, but data at high $\mathrm{Ca}$ concentrations are absent; the intersection of this curve with $\mathrm{A}$ occurs at a $\mathrm{Ca} / \mathrm{Si}$ ratio near 1.

Interpretations. - Although more curves may be present, Figure 10 suggests the existence of a family of well-defined solubility curves at high Ca concentrations; $\mathrm{C}-\mathrm{S}-\mathrm{H}$ thus does not solely equilibrate with aqueous solution on or near curve A as is generally assumed. Although there is some consistency in the equilibria of products from double decomposition (which tend to follow either curve A or C"), as a whole, the variations in solubility do not appear to be unambiguously related to processing variables such as temperature, starting materials, and aging time. Nevertheless, in light of the structural differences illustrated in the $\mathrm{C}-\mathrm{S}-\mathrm{H}$ solids equilibrated on curves $\mathrm{C}$ and $\mathrm{C}$ ", it is hypothesized that the $\mathrm{C}-\mathrm{S}-\mathrm{H}$ associated with each curve in Figure 10 represents a distinct metastable phase of unique structure. Indeed, the parallel nature of the curves $\mathrm{C}, \mathrm{C}^{\prime}$, and $\mathrm{C}^{\prime \prime}$ seems to suggest that the variations in solubility result from some variable structural feature of $\mathrm{C}-\mathrm{S}-\mathrm{H}$. In ensuing sections, it will be argued that curves $\mathrm{C}, \mathrm{C}^{\prime}$, and $\mathrm{C}^{\prime \prime}$ arise from the variations in the content of $\mathrm{Ca}-\mathrm{OH}$ in $\mathrm{C}-\mathrm{S}-\mathrm{H}$.

Modification of Curve $B$ at high Ca concentration. - The establishment of curve $\mathrm{C}$ suggested that the published solubility data during the hydration of $\mathrm{C}_{3} \mathrm{~S}$ clustered near $20 \mathrm{mM}$ Ca should be assigned to curve $\mathrm{C}$ rather than to curve $\mathrm{B}$ as originally drawn [47]. Curve $\mathrm{B}$ was thus redrawn while incorporating

\footnotetext{
${ }^{\dagger}$ The data set from Brown et al. [77] is perhaps the only one to indicate concentrations on curve A during the early hydration of $\mathrm{C}_{3} \mathrm{~S}$; all others follow curve $\mathrm{B}$. The cause for this discrepancy may be due to differences in experimental methods, but the precise conditions have not been determined. For example, others [49,75] have shown that the concentrations can be induced from curve B to, or near, curve A if the suspensions are filtered; this could account for the Brown et al. [77] data, but attempts to reproduce them have been unsuccessful [79], suggesting that other factors could be involved.
} 
data from studies $[75,81,82]$ that report solubilities in the region supersaturated with respect to $\mathrm{CH}$; these data are represented as filled symbols in Figure 10.

Modification of the $\mathrm{CH}$ solubility curve. - Since the results of this study and of those represented in Figure 10 suggest that $\mathrm{C}-\mathrm{S}-\mathrm{H}$ is in equilibrium with $\mathrm{CH}$ at $\sim 20.6 \mathrm{mM} \mathrm{Ca}$ (i.e., the solubility of pure $\mathrm{CH}$ at $\left.22-24{ }^{\circ} \mathrm{C}[83,84]\right)$, the solubility curve for $\mathrm{CH}$, which originally curved to higher $\mathrm{Ca}$ concentrations with increasing Si concentrations, was redrawn as shown in Figure 10.

5.2. Hypothesis for structural variations in $\mathbf{C}-\mathbf{S}-\mathbf{H}$ at high $\mathbf{C a} / \mathbf{S i}$ ratios. Figure 10 shows that the most significant variations in solubility of metastable $\mathrm{C}-\mathrm{S}-\mathrm{H}$ phases occur at $\mathrm{Ca} / \mathrm{Si}$ ratios above $\sim 1$. Since solubility and structure are coupled, the problem in rationalizing the variations in solubility reduces to explaining how the structure of $\mathrm{C}-\mathrm{S}-\mathrm{H}$ can vary at high $\mathrm{Ca} / \mathrm{Si}$ ratios. A fundamental premise of the present hypothesis is that a given $\mathrm{Ca} / \mathrm{Si}$ ratio can arise from more than one ionic constitution. $\mathrm{C}-\mathrm{S}-\mathrm{H}$ with a $\mathrm{Ca} / \mathrm{Si}$ ratio of 0.8 , for example, can increase its $\mathrm{Ca} / \mathrm{Si}$ ratio through (1) omission of bridging silicate tetrahedra with or without substitution of interlayer $\mathrm{Ca}$, (2) increase in interlayer $\mathrm{Ca}$ balanced by loss of protons from $\mathrm{Si}-\mathrm{OH}$ groups, (3) increase in $\mathrm{Ca}$ balanced by $\mathrm{OH}$ (i.e., $\mathrm{Ca}-\mathrm{OH}$ ), or (4) various combinations of these. Thus, in the range of $\mathrm{Ca} / \mathrm{Si}$ ratio above $\sim 1$ with which we are most concerned, a given $\mathrm{Ca} / \mathrm{Si}$ ratio can theoretically be achieved by a combination of small mean chain length (i.e., many missing bridging tetrahedra) and low $\mathrm{Ca}-\mathrm{OH}$ content, or by a high mean chain length (i.e., more bridging tetrahedra) and high $\mathrm{Ca}-\mathrm{OH}$ content.

It is proposed here that, at a given $\mathrm{Ca} / \mathrm{Si}$ ratio, $\mathrm{C}-\mathrm{S}-\mathrm{H}$ has a high mean chain length and a high $\mathrm{Ca}-\mathrm{OH}$ content when equilibrated with aqueous solution on a curve such as $\mathrm{C}$ and progressively lower mean chain lengths and $\mathrm{Ca}-\mathrm{OH}$ contents when equilibrated on curves with progressively lower $\mathrm{Si}$ concentrations such as $\mathrm{C}^{\prime}, \mathrm{C}^{\prime \prime}$, and $\mathrm{A}$.

Support from mean silicate chain lengths. - The ${ }^{29} \mathrm{Si}$ NMR results presented in Figure 7 provide direct support of the above hypothesis since, at a given $\mathrm{Ca} / \mathrm{Si}$ ratio, the mean silicate chain lengths of solids from the $\mathrm{C}_{3} \mathrm{~S}$ group that equilibrated on curve $\mathrm{C}$ were consistently higher than those of solids from the double decomposition group that equilibrated on $\mathrm{C}$ ". The literature suggests an even lower degree of polymerization in solids equilibrated on curve A. For example, Brown et al. [77] measured solubility during the first $4 \mathrm{~h}$ of $\mathrm{C}_{3} \mathrm{~S}$ hydration and produced data exclusively on curve A; since ${ }^{29} \mathrm{Si}$ NMR studies $[50,85-87]$ have shown that the first $\mathrm{C}-\mathrm{S}-\mathrm{H}$ product after the induction period is dimeric, the mean chain lengths associated with solids equilibrated on curve A must be low, most likely reaching a minimum value of 2 at $\mathrm{CH}$ saturation. This conclusion is supported from a ${ }^{29} \mathrm{Si}$ NMR study [88], which showed that the mean silicate chain lengths in double decomposition-derived $\mathrm{C}-\mathrm{S}-\mathrm{H}$ specimens with nominal $\mathrm{Ca} / \mathrm{Si}$ ratios of $0.79-1.5$ were 2.8-2.2. These mean chain lengths are correspondingly lower than those of the double decomposition group reported here, and since the products of double decomposition appear to equilibrate only along curves $\mathrm{A}$ or $\mathrm{C}^{\prime \prime}$ with a maximum $\mathrm{Ca} / \mathrm{Si}$ ratio of 1.5 (Table 6), the data appear to indicate again that the mean chain length in solids equilibrated on curve $\mathrm{A}$ are limited to the minimum value of 2 at $\mathrm{CH}$ saturation.

5.3. Charge balance calculation for $\mathbf{C a}-\mathbf{O H}$. The central hypothesis here is that the point at which the aqueous concentrations depart from curve $\mathrm{A}$ onto, for example, curve $\mathrm{C}$ coincides with the change from incorporating $\mathrm{Ca}$ in interlayer sites along curve $\mathrm{A}$ to incorporating $\mathrm{Ca}$ in $\mathrm{Ca}-\mathrm{OH}$ sites along curve $\mathrm{C}$. Therefore, for the curves depicted in Figure 10, $\mathrm{Ca}-\mathrm{OH}$ bonds first appear in $\mathrm{C}-\mathrm{S}-\mathrm{H}$ at the points of intersection of curve $\mathrm{A}$ with curves $\mathrm{C}, \mathrm{C}^{\prime}$, and $\mathrm{C}^{\prime \prime}$. The $\mathrm{Ca} / \mathrm{Si}$ ratio at these points is shown below by a charge balance calculation to correspond to the minimum $\mathrm{Ca} / \mathrm{Si}$ ratio at which $\mathrm{Ca}-\mathrm{OH}$ must form. 
This calculation (derived in Appendix A) is a generalization of that performed by Cong and Kirkpatrick [3] and is similar to the approach by Richardson and Groves [89]. The main assumption is that a single dreierketten structure with a variable mean chain length, $l$, is present. Since a distribution of chain lengths is possible, the mean chain length is not restricted to the $(3 n-1)$ values expected for a fragmented dreierketten, and its numerical value need not be integral. The silicate anions in the dreierketten can be balanced by protons or $\mathrm{Ca}$, and evidence from IR spectroscopy [12] and ${ }^{29} \mathrm{Si}$ NMR [3] suggest that, with increasing $\mathrm{Ca} / \mathrm{Si}$ ratio, all protons in $\mathrm{Si}-\mathrm{OH}$ groups are replaced with interlayer $\mathrm{Ca}$ before additional $\mathrm{Ca}$ (in excess of that required to balance silicate anions) is introduced as $\mathrm{Ca}-\mathrm{OH}$. These mechanisms therefore suggest that $\mathrm{Si}-\mathrm{OH}$ and $\mathrm{Ca}-\mathrm{OH}$ groups do not coexist, and at the points of intersection in Figure 10 between curve $\mathrm{A}$ and the family of curves related to $\mathrm{C}$, it is proposed that neither is present.

Given these assumptions, the general formula for $\mathrm{C}-\mathrm{S}-\mathrm{H}$ at the points of intersection is $\mathrm{Ca}_{6}\left(\mathrm{Si}_{6-x} \mathrm{O}_{18-2 x}\right)$ $\cdot n \mathrm{H}_{2} \mathrm{O}$ (referred to 6 tetrahedral sites), where $x$ need not be integral; the $\mathrm{Ca} / \mathrm{Si}$ ratios at the points of intersection are $(l+1) / l$, where $l$ is the mean chain length (see Appendix A). The Ca/Si ratios computed for several mean chain lengths in Table 5 correspond to the minimum $\mathrm{Ca} / \mathrm{Si}$ above which $\mathrm{Ca}-\mathrm{OH}$ must form. These values agree with the experimentally measured $\mathrm{Ca} / \mathrm{Si}$ ratios and mean chain lengths found at the points of intersection in Figure 10: for example, sample $3 \mathrm{~b}^{*}$ (the closest to the intersection of curves A and $\mathrm{C}$ ) showed a mean chain length of 5.0 and a $\mathrm{Ca} / \mathrm{Si}$ ratio of 1.22 , the latter thus agreeing with the computed value of 1.20 (Table 5); sample 6b" (the closest to the intersection of curves A and C") showed a mean chain length of 2.9 and a $\mathrm{Ca} / \mathrm{Si}$ ratio of 1.28 , the latter agreeing with the computed value of 1.33. Further support is found in solids equilibrated at the intersection of curve A and the $\mathrm{CH}$ solubility curve, where the literature suggests a mean chain length of 2 (Section 5.2) and a $\mathrm{Ca} / \mathrm{Si}$ ratio of 1.5 (Table 6); these values coincide with the calculation (Table 5). The above agreements therefore support our association of solubility curves $\mathrm{C}, \mathrm{C}^{\prime}$, and $\mathrm{C}^{\prime \prime}$ with the occurrence of $\mathrm{Ca}-\mathrm{OH}$ bonds in $\mathrm{C}-\mathrm{S}-\mathrm{H}$.

Metastable phase boundaries. - As noted above, since a distribution of chain lengths may exist [90], the mean silicate chain length in $\mathrm{C}-\mathrm{S}-\mathrm{H}$ need not be integral; the $\mathrm{Ca} / \mathrm{Si}$ ratios computed in Table 5 are thus merely an arbitrary selection. In principle, an infinite number of combinations of mean silicate chain length and $\mathrm{Ca} / \mathrm{Si}$ ratio could be present at the points of intersection of curve $\mathrm{A}$ with a curve similar to $\mathrm{C}$, which would imply (according to our hypothesis) an infinite number of solubility curves at high $\mathrm{Ca}$ concentration. The fact that the data in Figure 10 excluding those following curve B show only 4-5 curves either suggests that the distributions in chain length are restricted in some way or that agreements among different data sets on a single curve (e.g., curve C") are fortuitous. Despite this uncertainty, the calculations in Table 5 suggest metastable phase boundaries. At one extreme, when the mean chain length is a minimum of 2 and the $\mathrm{Ca} / \mathrm{Si}$ ratio is 1.5 at $\mathrm{CH}$ saturation, a $\mathrm{C}-\mathrm{S}-\mathrm{H}$ phase equilibrates exclusively along curve A while maintaining a purely tobermorite-like structure (i.e., one with no $\mathrm{Ca}-\mathrm{OH}$ ). At the other extreme, when the mean chain length is infinitely long at an intersection point, $\mathrm{Ca}-\mathrm{OH}$ bonds will form at the minimum $\mathrm{Ca} / \mathrm{Si}$ ratio of 1 ; this establishes what may be called curve $\mathrm{C}^{0}$, the solubility curve with the highest $\mathrm{Si}$ concentrations, which relates to a $\mathrm{C}-\mathrm{S}-\mathrm{H}$ phase of maximum $\mathrm{Ca}-\mathrm{OH}$ content. All other metastable $\mathrm{C}-\mathrm{S}-\mathrm{H}$ phases with intermediate mean chain lengths and $\mathrm{Ca}-\mathrm{OH}$ contents would be expected to fall between curves $A$ and $C^{0}$. The curve suggested by the data of Grutzeck et al. [17] (Figure 10) may approximately correspond to curve $C^{0}$.

$\mathrm{Ca}-\mathrm{OH}$ content. - For curves $\mathrm{C}, \mathrm{C}^{\prime}, \mathrm{C}^{\prime \prime}$, and $\mathrm{A}$, the above interpretation implies that the highest $\mathrm{Ca}-\mathrm{OH}$ content in $\mathrm{C}-\mathrm{S}-\mathrm{H}$ is found on curve $\mathrm{C}$ and progressively lower values on $\mathrm{C}^{\prime}, \mathrm{C}^{\prime \prime}$, and finally $\mathrm{A}$. This can be checked by a charge balance calculation if it is assumed (as above) that the $\mathrm{Ca}-\mathrm{OH}$ content represents 
the $\mathrm{Ca}$ in excess of that required to solely charge balance the silicate anions (i.e., $\mathrm{Si}-\mathrm{OH}$ are assumed absent). Thus, the $\mathrm{Ca}-\mathrm{OH}$ content (i.e., the fraction of $\mathrm{Ca}$ in $\mathrm{C}-\mathrm{S}-\mathrm{H}$ balanced by $\mathrm{OH}$ ) can be expressed as $\lfloor\mathrm{Ca} / \mathrm{Si} \square(l+1) / l\rfloor \mathrm{Ca} / \mathrm{Si}$. Using this expression and the data in Table 4, it is seen that the $\mathrm{Ca}-\mathrm{OH}$ content is higher for solids on curve $\mathrm{C}$ than on curve $\mathrm{C}^{\prime \prime}$ : for example, at $\mathrm{CH}$ saturation, the fraction of $\mathrm{Ca}$ balanced by $\mathrm{OH}$ is $\sim 25 \%$ in $\mathrm{C}-\mathrm{S}-\mathrm{H}$ gel (from $\mathrm{C}_{3} \mathrm{~S}$ paste) on curve $\mathrm{C}$ and $4-5 \%$ in $\mathrm{C}-\mathrm{S}-\mathrm{H}$ (from double decomposition) on curve $\mathrm{C}^{\prime \prime}$. The value for $\mathrm{C}-\mathrm{S}-\mathrm{H}$ gel from the 8-month hydrated $\mathrm{C}_{3} \mathrm{~S}$ paste agrees with the $23 \%$ value measured directly by inelastic neutron scattering [36], thereby giving some validation for the assumption of zero $\mathrm{Si}-\mathrm{OH}$ content. Moreover, since the $\mathrm{Ca} / \mathrm{Si}$ ratio in $\mathrm{C}-\mathrm{S}-\mathrm{H}$ gel remains essentially constant with age at 1.8 [29], and since the mean chain length ultimately converges to a value of $5[58,86]$ the above expression also expects that the $\mathrm{Ca}-\mathrm{OH}$ content in $\mathrm{C}-\mathrm{S}-\mathrm{H}$ gel eventually reaches $33 \%$, the theoretical value for jennite.

Spectrum of $\mathrm{C}-\mathrm{S}-\mathrm{H}$ structures. - If it is assumed that $\mathrm{Ca}-\mathrm{OH}$ bonds in $\mathrm{C}-\mathrm{S}-\mathrm{H}$ occur in the main $\mathrm{Ca}-\mathrm{O}$ layer as in jennite, a high $\mathrm{Ca}-\mathrm{OH}$ content would be expected to encourage the formation of a jennite-like structure [1] (see arguments in Section 1.3). Thus, the above results suggest a spectrum of $\mathrm{C}-\mathrm{S}-\mathrm{H}$ structures, ranging from a purely tobermorite-like structure on curve A to a largely jennite-like structure on curve $\mathrm{C}$ (and $\mathrm{C}^{0}$ ). Moreover, the equilibration of $\mathrm{C}-\mathrm{S}-\mathrm{H}$ gel from $\mathrm{C}_{3} \mathrm{~S}$ paste on curve $\mathrm{C}$ gives additional evidence [32] that the structure of $\mathrm{C}-\mathrm{S}-\mathrm{H}$ gel at late times is more closely jennite-like than tobermorite-like. In contrast, the equilibration of double-decomposition derived $\mathrm{C}-\mathrm{S}-\mathrm{H}$ on curve $\mathrm{C}$ " suggests a closer resemblance to 1.4-nm tobermorite.

5.4. Variations in $\mathbf{C a} / \mathbf{S i}$ ratio of $\mathbf{C}-\mathbf{S}-\mathbf{H}$ at $\mathbf{C H}$ saturation. A long-standing conundrum in the $\mathrm{CaO}-\mathrm{SiO}_{2}-\mathrm{H}_{2} \mathrm{O}$ system at room temperature is the cause of the variation in published values of the $\mathrm{Ca} / \mathrm{Si}$ ratio of $\mathrm{C}-\mathrm{S}-\mathrm{H}$ equilibrated with aqueous solution saturated with $\mathrm{CH}$. Steinour [46] cites values ranging from 1.3-2, and Table 6 gives a selection of these, with some obtained more recently. Except for preparations made by double decomposition, for which all the data indicate a $\mathrm{Ca} / \mathrm{Si}$ ratio near 1.5 (Table 6 ), there is no apparent relation to the method of preparation, and no adequate explanation has been offered.

Evidence presented in earlier sections indicate that $\mathrm{Ca} / \mathrm{Si}$ ratios near 1.5 at $\mathrm{CH}$ saturation arise from structures devoid of $\mathrm{Ca}-\mathrm{OH}$ and are thus mainly or wholly based on 1.4-nm tobermorite. It is hypothesized that higher $\mathrm{Ca} / \mathrm{Si}$ ratios at $\mathrm{CH}$ saturation are present in structures with varying proportions of $\mathrm{Ca}-\mathrm{OH}$, perhaps depending on the extent to which $\mathrm{Ca}-\mathrm{OH}$ is segregated into regions of jennite-like structure. For the curves present in Figure 10, higher $\mathrm{Ca} / \mathrm{Si}$ ratios would thus be expected to be associated with curve $\mathrm{C}$, lower ones with curve $\mathrm{A}$, and intermediate values in between; although scatter exists, the data in Table 6 are largely consistent with these expected trends.

Some of the scatter in Table 6 may possibly be attributed to higher preparation temperatures. Fujii and Kondo [78] have shown in preparations of $\mathrm{C}-\mathrm{S}-\mathrm{H}$ from double decomposition that the $\mathrm{Ca} / \mathrm{Si}$ ratio at $\mathrm{CH}$ saturation can reach 1.87 if reacted at $50{ }^{\circ} \mathrm{C}$ but only $\sim 1.5$ at $20{ }^{\circ} \mathrm{C}$. This result may thus account for why the $\mathrm{C}-\mathrm{S}-\mathrm{H}$ of Greenberg and Chang [52] prepared from $\mathrm{CH}$ and $\mathrm{SiO}_{2}$ at $50{ }^{\circ} \mathrm{C}$ (and equilibrated at $25{ }^{\circ} \mathrm{C}$ ) reached a value of 1.75 on curve $C^{\prime \prime}$, while other preparations on the same curve reacted between 22-30 ${ }^{\circ} \mathrm{C}$ ([76], double decomposition in this study) only reached a maximum of $\sim 1.5$.

5.4. Differences between synthetic $\mathbf{C}-\mathbf{S}-\mathbf{H}$ and $\mathbf{C}-\mathbf{S}-\mathbf{H}$ gel. The family of solubility curves in Figure 10 highlights the structural diversity of $\mathrm{C}-\mathrm{S}-\mathrm{H}$. At $\mathrm{CH}$ saturation, for example, the structure of $\mathrm{C}-\mathrm{S}-\mathrm{H}$ can be tobermorite-like with a $\mathrm{Ca} / \mathrm{Si}$ ratio of 1.5 if equilibrated on curve $\mathrm{A}$ and jennite-like with a $\mathrm{Ca} / \mathrm{Si}$ ratio of 1.8 if equilibrated on curve $\mathrm{C}$. Although the precise conditions under which these structures form 
is yet determined, it seems impossible to form much $\mathrm{Ca}-\mathrm{OH}$ in $\mathrm{C}-\mathrm{S}-\mathrm{H}$ made by double decomposition at room temperature, for which the $\mathrm{Ca} / \mathrm{Si}$ ratio is therefore limited to $\sim 1.5$, and it appears generally difficult to form much $\mathrm{Ca}-\mathrm{OH}$ in $\mathrm{C}-\mathrm{S}-\mathrm{H}$ from lime and silica or from $\mathrm{C}_{3} \mathrm{~S}$ reacted in dilute aqueous suspension; 'synthetic' C-S-H preparations such as these thus tend to form tobermorite-like phases that equilibrate near curve $\mathrm{A}$. In contrast, $\mathrm{C}-\mathrm{S}-\mathrm{H}$ gel in $\mathrm{C}_{3} \mathrm{~S}$ pastes has a high $\mathrm{Ca}-\mathrm{OH}$ content [36] and invariably obtains a high $\mathrm{Ca} / \mathrm{Si}$ ratio of 1.8 when coexisting with portlandite [24-31]; $\mathrm{C}-\mathrm{S}-\mathrm{H}$ gel thus tends to jennite-like phases that equilibrate near curve $\mathrm{C}$. These trends therefore suggest that the structures of synthetic $\mathrm{C}-\mathrm{S}-\mathrm{H}$ and $\mathrm{C}-\mathrm{S}-\mathrm{H}$ gel from $\mathrm{C}_{3} \mathrm{~S}$ pastes are generally (but not always) distinct. Moreover, it may be misleading in some instances to extrapolate conclusions about the nanostructure of $\mathrm{C}-\mathrm{S}-\mathrm{H}$ gel from data on synthetic $\mathrm{C}-\mathrm{S}-\mathrm{H}$, especially those produced from double decomposition. For greater insight into the structure of $\mathrm{C}-\mathrm{S}-\mathrm{H}$ gel, it appears more appropriate to analyze single-phase, homogeneous specimens prepared by the decalcification/recalcification of $\mathrm{C}_{3} \mathrm{~S}$ pastes as done here; further details on this preparation procedure are given elsewhere [57].

\section{Conclusions}

New phase equilibrium results and a reassessment of published data demonstrate the existence in the $\mathrm{CaO}-\mathrm{SiO}_{2}-\mathrm{H}_{2} \mathrm{O}$ system at room temperature of a family of solubility curves designated here as curves $\mathrm{C}$, C', C", and A (Figure 10); additional curves may be present. Since these curves were reversibly approached from the decalcification of a high $\mathrm{Ca} / \mathrm{Si}$ solid and the recalcification of a low $\mathrm{Ca} / \mathrm{Si}$ solid, and since these curves were shown by ${ }^{29} \mathrm{Si}$ NMR and charge balance calculations to be associated with solids having distinct structures at a given $\mathrm{Ca} / \mathrm{Si}$ ratio, it was concluded that the family of curves represent solubilities for a spectrum of metastable $\mathrm{C}-\mathrm{S}-\mathrm{H}$ phases. Specific points are summarized below.

1. When $\mathrm{C}-\mathrm{S}-\mathrm{H}$ and an aqueous phase are in equilibrium at constant temperature and pressure, the Gibbs phase rule predicts that this 3-component system has 1 degree of freedom, a mole fraction in either phase. Thus, a solubility curve that is established when plotting aqueous $\mathrm{Ca}$ and $\mathrm{Si}$ concentrations against each other is associated with a single $\mathrm{C}-\mathrm{S}-\mathrm{H}$ phase.

2. $\mathrm{C}-\mathrm{S}-\mathrm{H}$ with solubilities following exclusively curve $\mathrm{A}$ up to saturation in $\mathrm{CH}$ lack $\mathrm{Ca}-\mathrm{OH}$ and thus have structures based purely on 1.4-nm tobermorite. At $\mathrm{CH}$ saturation, these structures have a $\mathrm{Ca} / \mathrm{Si}$ ratio of 1.5 and a minimum mean chain length of 2 .

3. The departures in solubility from curve A onto curves $\mathrm{C}, \mathrm{C}^{\prime}$, and $\mathrm{C}^{\prime \prime}$ are due to the formation of $\mathrm{Ca}-\mathrm{OH}$ bonds in $\mathrm{C}-\mathrm{S}-\mathrm{H}$. Assuming that $\mathrm{Si}-\mathrm{OH}$ and $\mathrm{Ca}-\mathrm{OH}$ do not coexist in $\mathrm{C}-\mathrm{S}-\mathrm{H}$, the $\mathrm{Ca} / \mathrm{Si}$ ratios at which these departures occur can be expressed as $(l+1) / l$, where $l$ is the mean chain length; these values correspond to the minimum $\mathrm{Ca} / \mathrm{Si}$ ratios above which $\mathrm{Ca}-\mathrm{OH}$ bonds must form. For $\mathrm{C}-\mathrm{S}-\mathrm{H}$ gel from $\mathrm{C}_{3} \mathrm{~S}$ paste, the formation of $\mathrm{Ca}-\mathrm{OH}$ occurred at the intersection of curves $\mathrm{A}$ and $\mathrm{C}$ when the mean chain length was 5 and the $\mathrm{Ca} / \mathrm{Si}$ ratio 1.2 .

4. The mean silicate chain length and the $\mathrm{Ca}-\mathrm{OH}$ content of $\mathrm{C}-\mathrm{S}-\mathrm{H}$ can vary at a given $\mathrm{Ca} / \mathrm{Si}$ ratio. For solids associated with curves $\mathrm{C}, \mathrm{C}^{\prime}, \mathrm{C}^{\prime \prime}$, and $\mathrm{A}$, the highest mean chain lengths and $\mathrm{Ca}-\mathrm{OH}$ contents at given $\mathrm{Ca} / \mathrm{Si}$ ratio above 1.2 are found along curve $\mathrm{C}$, and progressively lower values are found on $\mathrm{C}^{\prime}$, $\mathrm{C}$ ", and finally A. Assuming the absence of $\mathrm{Si}-\mathrm{OH}$, the $\mathrm{Ca}-\mathrm{OH}$ content (i.e., the fraction of $\mathrm{Ca}$ balanced by $\mathrm{OH})$ can be expressed as $[\mathrm{Ca} / \mathrm{Si} \square(l+1) / l\rfloor \mathrm{Ca} / \mathrm{Si}$. At $\mathrm{CH}$ saturation, the $\mathrm{Ca}-\mathrm{OH}$ content was $\sim 25 \%$ for $\mathrm{C}-\mathrm{S}-\mathrm{H}$ gel (from $\mathrm{C}_{3} \mathrm{~S}$ paste) on curve $\mathrm{C}$ and $4-5 \%$ in $\mathrm{C}-\mathrm{S}-\mathrm{H}$ (from double decomposition) on curve $\mathrm{C}^{\prime \prime}$. 
5. The $\mathrm{Ca} / \mathrm{Si}$ ratios at $\mathrm{CH}$ saturation are variable and are believed to be proportional to the $\mathrm{Ca}-\mathrm{OH}$ content in $\mathrm{C}-\mathrm{S}-\mathrm{H}$. This conclusion thus accounts for the discrepancy between the 1.8 value shown by $\mathrm{C}-\mathrm{S}-\mathrm{H}$ gel from $\mathrm{C}_{3} \mathrm{~S}$ paste and the 1.5 value shown by $\mathrm{C}-\mathrm{S}-\mathrm{H}$ from double decomposition. Broad variations in $\mathrm{Ca} / \mathrm{Si}$ ratio found at $\mathrm{CH}$ saturation in the literature may also be reconciled.

6. Assuming that high $\mathrm{Ca}-\mathrm{OH}$ contents are accommodated by a jennite-like conformation, the family of solubility curves represents a spectrum of metastable phases, ranging from a purely tobermorite-like structure on curve A to a largely jennite-like structure on curve $\mathrm{C}$. At $\mathrm{CH}$ saturation, $\mathrm{C}-\mathrm{S}-\mathrm{H}$ can therefore resemble either 1.4-nm tobermorite or jennite.

7. The structures of synthetic $\mathrm{C}-\mathrm{S}-\mathrm{H}$ (i.e., from aqueous suspension) and $\mathrm{C}-\mathrm{S}-\mathrm{H}$ gel from $\mathrm{C}_{3} \mathrm{~S}$ pastes are generally (but not always) distinct. For greater insight into the $\mathrm{C}-\mathrm{S}-\mathrm{H}$ gel structure, it thus appears more appropriate to conduct studies on single-phase specimens obtained directly from $\mathrm{C}_{3} \mathrm{~S}$ pastes.

\section{Appendix A: Charge balance calculation for the presence of $\mathrm{Ca}-\mathrm{OH}$ in $\mathrm{C}-\mathrm{S}-\mathrm{H}$}

The charge balance calculation in Table 5 calculates, as a function of mean silicate chain length, the $\mathrm{Ca} / \mathrm{Si}$ ratio above which $\mathrm{Ca}-\mathrm{OH}$ must be present in $\mathrm{C}-\mathrm{S}-\mathrm{H}$. This calculation is a generalization of that performed by Cong and Kirkpatrick [3] and is similar to the approach by Richardson and Groves [89]. The derivation is as follows.

1. Assume a single dreierketten structure (as in 1.4- $\mathrm{nm}$ tobermorite) with the possibility of a variable mean chain length, $l$.

2. For each individual chain, there are $(l+1)$ tetrahedra sites (one is a vacant bridging tetrahedra site); hence, per 6 tetrahedral sites, there are $6 l /(l+1)$ Si atoms.

3. Irrespective of mean chain length, each chain contains $(3 l+1) / l \mathrm{O}$ atoms per $\mathrm{Si}$ atom.

4. Thus, per 6 tetrahedral sites, there are $[6 l /(l+1) \square(3 l+1) / l]=6(3 l+1) /(l+1) \mathrm{O}$ atoms.

5. At the points of intersection of curves $\mathrm{A}$ with $\mathrm{C}, \mathrm{C}^{\prime}$, and $\mathrm{C}^{\prime \prime}$, neither $\mathrm{Si}-\mathrm{OH}$ or $\mathrm{Ca}-\mathrm{OH}$ exist. The $\mathrm{O}$ atoms in the assemblage in (4) thus requires $6(3 l+1) /(l+1)-12 l /(l+1)=6 \mathrm{Ca}$ atoms.

6. The resulting $\mathrm{Ca} / \mathrm{Si}$ ratio, equal to $(l+1) / l$, is the minimum value at which $\mathrm{Ca}-\mathrm{OH}$ groups must occur in $\mathrm{C}-\mathrm{S}-\mathrm{H}$.

Acknowledgment. This paper is dedicated to Hal-he will be missed. The work was supported by the National Science Foundation under Grant No. CMS-0070922/001. 


\section{References}

[1] H.F.W. Taylor, Cement Chemistry, 2nd ed., Thomas Telford, London, 1997.

[2] S. Merlino, E. Bonaccorsi, A.R. Kampf, Tobermorite 14Å: crystal structure and OD character, in: D. Rammlmair, J. Mederer, T. Oberthür, R.B. Heimann, H. Pentinghaus (Eds.), Applied Mineralogy, Balkema, Rotterdam, 2000, pp. 859-861.

[3] X. Cong, R.J. Kirkpatrick, ${ }^{29}$ Si MAS NMR study of the structure of calcium silicate hydrate, Advn. Cem. Based. Mat. 3 (1996) 144-156.

[4] I. Klur, B. Pollet, J. Virlet, A. Nonat, C-S-H structure evolution with calcium content by multinuclear NMR, in: P. Colombet, A.-R. Grimmer, H. Zanni, P. Sozzani (Eds.), Nuclear Magnetic Resonance Spectroscopy of Cement-Based Materials, Springer, Berlin, 1998, pp. 119-141.

[5] S. Merlino, E. Bonaccorsi, T. Armbruster, Tobermorites: their real structure and order-disorder (OD) character, Am. Mineral. 84 (1999) 1613-1621.

[6] S. Merlino, E. Bonaccorsi, T. Armbruster, The real structure of clinotobermorite and tobermorite $9 \AA$ : OD character, polytypes, and structural relationships, Eur. J. Mineral. 12 (2000) 411-429.

[7] H.D. Megaw, C.H. Kelsey, Crystal structure of tobermorite, Nature 177 (1956) 390-391.

[8] S.A. Hamid, The crystal structure of the $11 \AA$ natural tobermorite $\mathrm{Ca}_{2.25}\left[\mathrm{Si}_{3} \mathrm{O}_{7.5}(\mathrm{OH})_{1.5}\right] \cdot 1 \mathrm{H}_{2} \mathrm{O}, \mathrm{Z}$. Kristallogr. 154 (1981) 189-198.

[9] E. Bonaccorsi, S. Merlino, H.F.W. Taylor, The crystal structure of jennite, $\mathrm{Ca}_{9} \mathrm{Si}_{6} \mathrm{O}_{18}(\mathrm{OH})_{6} \cdot 8 \mathrm{H}_{2} \mathrm{O}$, Cem. Concr. Res. this issue (2004).

[10] H.F.W. Taylor. The calcium silicate hydrates, Proc. 5th Int. Symp. Chem. Cem., Cement Association of Japan, Tokyo, Japan, 1968, pp. 1-26.

[11] H.F.W. Taylor, J.W. Howison, Relationships between calcium silicates and clay minerals, Clay Minerals Bull. 3 (1956) 98-110.

[12] P. Yu, R.J. Kirkpatrick, B. Poe, P.F. McMillan, X. Cong, Structure of calcium silicate hydrate (C-S-H): near-, mid-, and far-infrared spectroscopy, J. Am. Ceram. Soc. 82 (3) (1999) 742-748.

[13] L.S. Dent Glasser, E.E. Lachowski, M.Y. Qureshi, H.P. Calhoun, D.J. Embree, W.D. Jamieson, C.R. Masson, Identification of some of the polysilicate components of trimethylsilylated cement paste, Cem. Concr. Res. 11 (1981) 775-780.

[14] K. Mohan, H.F.W. Taylor, A trimethylsilylation study of tricalcium silicate pastes, Cem. Concr. Res. 12 (1982) 25-31.

[15] J. Hirljac, Z.Q. Wu, J.F. Young, Silicate polymerization during the hydration of alite, Cem. Concr. Res. 13 (1983) 877-886.

[16] H. Matsuyama, J.F. Young, Effects of $\mathrm{pH}$ on precipitation of quasi-crystalline calcium silicate hydrate in aqueous solution, Adv. Cem. Res. 12 (2000) 29-33.

[17] M. Grutzeck, A. Benesi, B. Fanning, Silicon-29 magic angle spinning nuclear magnetic resonance study of calcium silicate hydrates, J. Am. Ceram. Soc. 72 (4) (1989) 665-668.

[18] D.E. Macphee, E.E. Lachowski, F.P. Glasser, Polymerization effects in C-S-H: implications for portland cement hydration, Adv. Cem. Res. 1 (1988) 131-137.

[19] Y. Okada, H. Ishida, T. Mitsuda, ${ }^{29} \mathrm{Si}$ NMR spectroscopy of silicate anions in hydrothermally formed C-S-H, J. Am. Ceram. Soc. 77 (1994) 765-768.

[20] N. Lequex, A. Morau, S. Philippot, P. Boch, Extended X-ray absorption fine structure investigation of calcium silicate hydrates, J. Am. Ceram. Soc. 82 (1999) 1299-1306.

[21] H.F.W. Taylor, Hydrated calcium silicates. Part I. Compound formation at ordinary temperatures, J. Chem. Soc. (1950) 3682-3690.

[22] J.A. Gard, H.F.W. Taylor, Calcium silicate hydrate (II) ("C-S-H(II)"), Cem. Concr. Res. 6 (1976) 667-678.

[23] S. Brunauer, S.A. Greenberg. The hydration of tricalcium silicate and $\square$-dicalcium silicate at room temperature, Proc. 4th Int. Symp. Chem. Cem., National Bureau of Standards, Washington, D.C., 1960, pp. 135-163. 
[24] L.S. Dent Glasser, E.E. Lachowski, K. Mohan, H.F.W. Taylor, A multi-method study of $\mathrm{C}_{3} \mathrm{~S}$ hydration, Cem. Concr. Res. 8 (1978) 733-740.

[25] P.J. Le Sueur, D.D. Double, G.W. Groves, Chemical and morphological studies of the hydration of tricalcium silicate, Proc. Br. Ceram. Soc. 35 (1984) 249-266.

[26] M.W. Grutzeck, D.M. Roy, Electron microprobe studies of the hydration of $3 \mathrm{CaO} \cdot \mathrm{SiO}_{2}$, Nature 223 (1969) 492-494.

[27] D.L. Rayment, A.J. Majumdar, The composition of the $\mathrm{C}-\mathrm{S}-\mathrm{H}$ phases in portland cement pastes, Cem. Concr. Res. 12 (1982) 133-140.

[28] H.F.W. Taylor, D.E. Newbury, An electron microprobe study of a mature cement paste, Cem. Concr. Res. 14 (1984) 565-573.

[29] I.G. Richardson, G.W. Groves, Microstructure and microanalysis of hardened ordinary portland cement pastes, J. Mater. Sci. 28 (1993) 265-277.

[30] G.W. Groves, P.J. Le Sueur, W. Sinclair, Transmission electron microscopy and microanalytical studies of ion-beam-thinned sections of tricalcium silicate paste, J. Am. Ceram. Soc. 69 (1986) $353-356$.

[31] I.G. Richardson, The nature of $\mathrm{C}-\mathrm{S}-\mathrm{H}$ in hardened cements, Cem. Concr. Res. 29 (1999) $1131-1147$.

[32] H.F.W. Taylor, Proposed structure for calcium silicate hydrate gel, J. Am. Ceram. Soc. 69 (1986) 464-467.

[33] X. Cong, R.J. Kirkpatrick, ${ }^{17} \mathrm{O}$ MAS NMR investigation of the structure of calcium silicate hydrate gel, J. Am. Ceram. Soc. 79 (6) (1996) 1585-1592.

[34] R. Rassem, H. Zanni-Théveneau, D. Heidemann, A.-R. Grimmer, Proton high resolution solid state NMR study of $\mathrm{C}_{3} \mathrm{~S}$ hydration, Cem. Concr. Res. 23 (1993) 169-176.

[35] D. Heidemann, W. Wieker. Characterization of protons in $\mathrm{C}-\mathrm{S}-\mathrm{H}$ phases by means of high-speed ${ }^{1} \mathrm{H}$ MAS NMR investigations, in: P. Colombet, A.-R. Grimmer, H. Zanni, P. Sozzani (Eds.), Nuclear Magnetic Resonance Spectroscopy of Cement Based Materials, Springer, Berlin, 1998, pp. 169-180.

[36] J.J. Thomas, J.J. Chen, D.A. Neumann, H.M. Jennings, Ca-OH bonding in the C-S-H gel phase of tricalcium silicate and white portland cement pastes measured by inelastic neutron spectroscopy, Chem. Mater. 15 (2003) 3813-3817.

[37] D.L. Kantro, S. Brunauer, C.H. Weise, Development of surface in the hydration of calcium silicates, in: R.F. Gould (Ed.), Advances in Chemistry Series, American Chemical Society, Washington, D.C., 1961, pp. 199-219.

[38] A. Bentur, R.L. Berger, Chemical composition of C-S-H gel formed in the hydration of calcium silicate pastes, J. Am. Ceram. Soc. 62 (3-4) (1978) 117-120.

[39] J.J. Thomas, J.J. Chen, A.J. Allen, H.M. Jennings, Effects of decalcification on the microstructure and surface area of cement and tricalcium silicate pastes, Cem. Concr. Res., in press.

[40] S. Brunauer, L.E. Copeland, R.H. Bragg, The stoichiometry of the hydration of tricalcium silicate at room temperature, I: hydration in a ball mill, J. Phys. Chem. 60 (1956) 112-120.

[41] R.W. Davis, J.F. Young, Hydration and strength development in tricalcium silicate pastes seeded with afwillite, J. Am. Ceram. Soc. 58 (1-2) (1975) 6770.

[42] U.R. Berner, Modeling the incongruent dissolution of hydrated cement minerals, Radiochim. Acta 44/45 (1988) 387-393.

[43] A.W. Harris, M.C. Manning, W.M. Tearle, C.J. Tweed, Testing of models of the dissolution of cements-leaching of synthetic C-S-H gels, Cem. Concr. Res. 32 (2002) 731-746.

[44] A. Atkinson, J.A. Hearne, C.F. Knights, Aqueous chemistry and thermodynamic modeling of $\mathrm{CaO}-\mathrm{SiO}_{2}-\mathrm{H}_{2} \mathrm{O}$ gels, J. Chem. Soc. Dalt. Trans. (1989) 2371-2379.

[45] H. Le Chatelier, Experimental researches on the constitution of hydraulic mortars (translation by J.L. Mack), Ann. Mines 11 (8) (1887) 345-465.

[46] H.H. Steinour, The system $\mathrm{CaO}-\mathrm{SiO}_{2}-\mathrm{H}_{2} \mathrm{O}$ and the hydration of the calcium silicates, Chem. Rev. 40 (1947) 391-460. 
[47] H.M. Jennings, Aqueous solubility relationships for two types of calcium silicate hydrate, J. Am. Ceram. Soc. 69 (1986) 614-618.

[48] H.N. Stein, Thermodynamic considerations on the hydration mechanisms of $\mathrm{Ca}_{3} \mathrm{SiO}_{5}$ and $\mathrm{Ca}_{3} \mathrm{Al}_{2} \mathrm{O}_{6}$, Cem. Concr. Res. 2 (1972) 167-177.

[49] P. Barret, D. Bertrandie, Comment on "Aqueous solubility relationships for two types of calcium silicate hydrate", J. Am. Ceram. Soc. 71 (2) (1988) C113-C115.

[50] S.A. Rodger, G.W. Groves, N.J. Clayden, C.M. Dobson, Hydration of tricalcium silicate followed by ${ }^{29}$ Si NMR with cross-polarization, J. Am. Ceram. Soc. 71 (2) (1988) 91-96.

[51] P. Barret, D. Ménétrier, D. Bertrandie, Mechanism of $\mathrm{C}_{3} \mathrm{~S}$ dissolution and problem of the congruency in the very initial period and later on, Cem. Concr. Res. 13 (1983) 728-738.

[52] S.A. Greenberg, T.N. Chang, Investigation of colloidal hydrated calcium silicates. II. Solubility relationships in the calcium oxide-silica-water system at $25^{\circ} \mathrm{C}$, J. Phys. Chem. 69 (1965) 182-188.

[53] A. Nonat, X. Lecoq., The structure, stoichiometry and properties of $\mathrm{C}-\mathrm{S}-\mathrm{H}$ prepared by $\mathrm{C}_{3} \mathrm{~S}$ hydration under controlled conditions, in: P. Colombet, A.-R. Grimmer, H. Zanni, P. Sozzani (Eds.), Nuclear Magnetic Resonance Spectroscopy of Cement-Based Materials, Springer, Berlin, 1998, pp. 197-207.

[54] L.E. Copeland, J.C. Hayes, Determination of non-evaporable water in hardened portland-cement paste, ASTM Bull. 194 (1953) 70-74.

[55] C. Carde, G. Escadeillas, R. Francois, Use of ammonium nitrate solution to simulate and accelerate the leaching of cement pastes due to deionized water, Mag. Concr. Res. 49 (181) (1997) 295-301.

[56] F.H. Heukamp, F.J. Ulm, J.T. Germaine, Mechanical properties of calcium-leached cement pastes: triaxial stress states and the influence of the pore pressures, Cem. Concr. Res. 31 (2001) 767-774.

[57] J.J. Chen, J.J. Thomas, H.M. Jennings, Preparation of single-phase C-S-H samples from hydrated tricalcium silicate pastes, Cem. Concr. Res., submitted for publication.

[58] J.J. Chen, The Nanostructure of Calcium Silicate Hydrate, Ph.D. Thesis, Dept. of Materials Science and Engineering, Northwestern University, Evanston, 2003.

[59] J.C. Farinas, P. Ortega, Chemical analysis of portland cement by inductively-coupled plasma atomic emission spectrometry, Analusis 20 (1992) 221-228.

[60] G.L. Kalousek, Studies of the portions of the quaternary system soda-lime-silica-water at $25^{\circ} \mathrm{C}$, J. Res. Natl. Bur. Stds. 32 (1944) 285-302.

[61] D.E. Macphee, K. Luke, F.P. Glasser, E.E. Lachowski, Solubility and aging of calcium silicate hydrates in alkaline solutions at $25^{\circ} \mathrm{C}$, J. Am. Ceram. Soc. 72 (4) (1989) 646-654.

[62] J.J. Thomas, J.J. Chen, A.J. Allen, H.M. Jennings, unpublished results.

[63] X. Cong, R.J. Kirkpatrick, ${ }^{29} \mathrm{Si}$ MAS NMR spectroscopic investigation of alkali silica reaction product gels, Cem. Concr. Res. 23 (1993) 811-823.

[64] A.R. Brough, C.M. Dobson, I.G. Richardson, G.W. Groves, Application of selective ${ }^{29}$ Si isotopic enrichment to studies of the structure of calcium silicate hydrate $(\mathrm{C}-\mathrm{S}-\mathrm{H})$ gels, J. Am. Ceram. Soc. 77 (2) (1994) 593-596.

[65] S. Komarneni, R. Roy, D.M. Roy, C.A. Fyfe, G.J. Kennedy, A.A. Bothner-By, J. Dadok, A.S. Chesnick, ${ }^{27} \mathrm{Al}$ and ${ }^{29} \mathrm{Si}$ magic angle spinning nuclear magnetic resonance spectroscopy of Alsubstituted tobermorites, J. Mater. Sci. 20 (1985) 4209-4214.

[66] G. Sun, A.R. Brough, J.F. Young, ${ }^{29} \mathrm{Si}$ NMR study of the hydration of $\mathrm{Ca}_{3} \mathrm{SiO}_{5}$ and $\left[-\mathrm{Ca}_{2} \mathrm{SiO}_{4}\right.$ in the presence of silica fume, J. Am. Ceram. Soc. 82 (1999) 3225-3230.

[67] H. Noma, Y. Adachi, H. Yamada, T. Nishino, Y. Matsuda, T. Yokoyama, ${ }^{29}$ Si MAS NMR spectroscopy of poorly-crystalline calcium silicate hydrates $(\mathrm{C}-\mathrm{S}-\mathrm{H})$, in: P. Colombet, A.-R. Grimmer, H. Zanni, P. Sozzani (Eds.), Nuclear Magnetic Resonance Spectroscopy of Cement-Based Materials, Springer, Berlin, 1998, pp. 119-141.

[68] F. Liebau, Bemerkungen zur Systematik der Kristallstrukturen von Silikaten mit Hochkondensierten Anionen (in German), Z. Phys. Chem. (Leipzig) 206 (1956) 73-92.

[69] N.V. Belov, Crystal Chemistry of Large-Cation Silicates, Consultants Bureau, New York, 1961. 
[70] A. Popova, G. Geoffroy, M.-F. Renou-Gonnard, P. Faucon, E. Gartner, Interactions between polymeric dispersants and calcium silicate hydrates, J. Am. Ceram. Soc. 83 (10) (2000) 2556-2560.

[71] H. Viallis, P. Faucon, J.C. Petit, A. Nonat, Interaction between salts ( $\mathrm{NaCl}, \mathrm{CsCl})$ and calcium silicate hydrates (C-S-H), J. Phys. Chem. B. 103 (1999) 5212-5219.

[72] D.L. Parkhurst, User's guide to PHREEQC - A computer program for speciation, reaction-path, advective-transport, and inverse geochemical calculations, United States Geological Survey, Lakewood, CO, 1995.

[73] J.J. Thomas, D. Rothstein, H.M. Jennings, B.J. Christensen, Effect of hydration temperature on the solubility behavior of Ca-, S-, Al-, and Si-bearing solid phases in portland cement pastes, Cem. Concr. Res. 33 (2003) 2037-2047.

[74] G.L. Kalousek. Application of differential thermal analysis in a study of the system lime-silica-water, Proc. 3rd Int. Symp. Chem. Cem., Cement and Concrete Association, London, 1952, pp. 296-311.

[75] E.P. Flint, L.S. Wells, Study of the system $\mathrm{CaO}-\mathrm{SiO}_{2}-\mathrm{H}_{2} \mathrm{O}$ at $30{ }^{\circ} \mathrm{C}$ and the reaction of water on the anhydrous calcium silicates, J. Res. Natl. Bur. Stds. (12) (1934) 751-783.

[76] P.S. Roller, G. Ervin, The system calcium oxide-silica-water at $30^{\circ} \mathrm{C}$. The association of silicate ion in dilute alkaline solution, J. Am. Chem. Soc. 62 (3) (1940) 461-471.

[77] P.W. Brown, E. Franz, G. Frohnsdorff, H.F.W. Taylor, Analyses of the aqueous phase during early $\mathrm{C}_{3} \mathrm{~S}$ hydration, Cem. Concr. Res. 14 (1984) 257-262.

[78] K. Fujii, W. Kondo, Heterogeneous equilibria of calcium silicate hydrate in water at $30{ }^{\circ} \mathrm{C}$, J. Chem. Soc. Dalt. Trans. 2 (1981) 645-651.

[79] H. Taleb, Analytical and mechanistic aspects of the action of selected retarders on the hydration of "tricalcium silicate", the major component of portland cement, Ph.D. Thesis, Dept. of Chemistry, Georgetown University, 1985.

[80] K. Fujii, W. Kondo, Estimation of thermochemical data for calcium silicate hydrate (C-S-H), J. Am. Ceram. Soc. 66 (12) (1983) C220-C221.

[81] K. Fujii, R. Kondo, Rate and mechanism of hydration of tricalcium silicate in an early stage, Nippon Seram. Kyo. Gak. 83 (5) (1975) 214-226.

[82] P. Barret, D. Bertrandie, Fundamental hydration kinetic features of the major cement constituents: $\mathrm{Ca}_{3} \mathrm{SiO}_{5}$ and $\left[-\mathrm{Ca}_{2} \mathrm{SiO}_{4}\right.$, J. Chim. Phys. 83 (11/12) (1983) 765-775.

[83] H. Bassett, Notes on the system lime-water, and on the determination of calcium, J. Chem. Soc. (1934) 1270-1275.

[84] R. Hedin, Saturation concentration of calcium hydroxide, Svenska Forskningsinstitutet for Cement Oct Betong Vid Kunkl. Tekniska Hogskolan I Stockholm 27 (1955) 3-13.

[85] E. Lippmaa, M. Magi, M. Tarmak, W. Wieker, A.R. Grimmer, A high resolution ${ }^{29}$ Si NMR study of the hydration of tricalcium silicate, Cem. Concr. Res. 12 (1982) 597-602.

[86] S.A. Rodger, G.W. Groves, N.J. Clayden, C.M. Dobson, A study of tricalcium silicate hydration from very early to very late stages, in: L.J. Struble, P.W. Brown (Eds.), Proc. Mat. Res. Soc. Symp., Materials Research Society, Pittsburgh, 1987, pp. 13-20.

[87] A.R. Brough, C.M. Dobson, I.G. Richardson, G.W. Groves, In situ solid-state NMR studies of $\mathrm{Ca}_{3} \mathrm{SiO}_{5}$ : hydration at room temperature and at elevated temperatures using ${ }^{29} \mathrm{Si}$ enrichment, J. Mater. Sci. 29 (1994) 3926-3940.

[88] X. Cong, R.J. Kirkpatrick, ${ }^{17} \mathrm{O}$ and ${ }^{29} \mathrm{Si}$ MAS NMR study of $\square-\mathrm{C}_{2} \mathrm{~S}$ hydration and the structure of calcium silicate hydrates, Cem. Concr. Res. 23 (1993) 1065-1077.

[89] I.G. Richardson, G.W. Groves, Models for the composition and structure of calcium silicate hydrate $(\mathrm{C}-\mathrm{S}-\mathrm{H})$ gel in hardened tricalcium silicate pastes, Cem. Concr. Res. 22 (1992) 1001-1010.

[90] X. Cong, R.J. Kirkpatrick, A ${ }^{1} \mathrm{H}^{29}$ Si CPMAS NMR study of the structure of calcium silicate hydrate, Adv. Cem. Res. 7 (1995) 103-111.

[91] G.E. Bessey. The calcium aluminate and silicate hydrates, Proc. Symp. Chem. Cem., Stockholm, 1938, pp. 179-215.

[92] J. Baylis, The system calcium oxide, silica and water, J. Phys. Chem. 32 (1928) 1236-1262. 
[93] A.J.P. van der Burgh, De Inwerking van Kalk op Kiezelzuur in Verband met de Verharding van Portland-Cement (in Dutch), Chem. Weekblad 29 (1932) 616-618.

[94] W.M. Shaw, W.H. MacIntire, The nature of calcium hydroxide absorption by hydrated silica, Soil Sci. 29 (1930) 429-456.

[95] H. Kühl, A. Mann, Calcium silicate hydrates. A contribution to the hardening theory of silicate cements (in German), Tonind.-Ztg 5 862-865,896-897,918-919,930-932,944-945,955-957,990-991,1003,1014-1016.

[96] T. Thorvaldson, V.A. Vigfusson, The action of water on tricalcium silicate and beta dicalcium silicate, Trans. Roy. Soc. Can. 3 (22(III)) (1928) 423-431.

[97] V. Cirilli, Calorimetric studies of the system $\mathrm{SiO}_{2}-\mathrm{CaO}-\mathrm{H}_{2} \mathrm{O}$ (in Italian), Ricerca Sci. 10 (1939) 459-461. 


\section{Figure Captions}

Figure 1. Single layer of 1.4-nm tobermorite seen along (a) [210] and (b) [010] illustrating the $\mathrm{Ca}-\mathrm{O}$ main layer (light gray) with attached dreierketten (dark gray). Water molecules and $\mathrm{Ca}$ atoms present in the interlayer spaces are omitted.

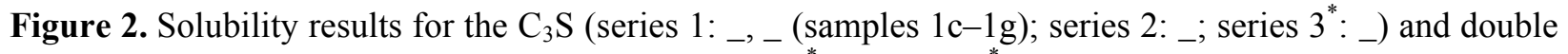
decomposition (series 4 : _, $\left(\right.$ samples $4 \mathrm{a}-4 \mathrm{c}$ ); series $5^{*}:_{-}$; series $6^{*}:_{-}$) groups. Unfilled and dotted points approach equilibrium by decalcification, filled and partially filled points by recalcification. $\mathrm{Ca} / \mathrm{Si}$ ratios of $\mathrm{C}-\mathrm{S}-\mathrm{H}$ are noted; the value enclosed in parenthesis refers to a sample containing $\mathrm{C}-\mathrm{S}-\mathrm{H}$ and $\mathrm{CH}$.

Figure 3. $\mathrm{Ca} / \mathrm{Si}$ ratio of the solid plotted versus the $\mathrm{Ca}$ concentration in aqueous solution at equilibrium. The $\mathrm{C}_{3} \mathrm{~S}$ group uses circles, double decomposition squares; unfilled and dotted points approach equilibrium by decalcification, filled and partially filled points by recalcification. See Tables 2 and 3 for further details on symbols. Samples $1 \mathrm{c}-1 \mathrm{~g}\left(\_\right)$are only believed to be in partial equilibrium.

Figure 4. $\mathrm{Ca} / \mathrm{Si}$ ratios measured by SEM-EDX across the thickness $(0.8 \mathrm{~mm})$ of a decalcified (_, _, _) and recalcified (_,_) $\mathrm{C}_{3} \mathrm{~S}$ paste. The different symbols in each series represent different traverses. The leached paste had a bulk $\mathrm{Ca} / \mathrm{Si}$ ratio of 0.83 ; the recalcified sample was a fragment of the leached specimen equilibrated for three weeks in $\mathrm{CH}$ solution, after which time the solid had a bulk $\mathrm{Ca} / \mathrm{Si}$ ratio near 1.3 and the $\mathrm{Ca}$ and Si concentrations in solution equilibrated on curve C. See Ref. [57] for further details.

Figure 5. XRD powder scans of selected samples from the $C_{3} S$ (samples $1 \mathrm{a}, 3 \mathrm{f}^{*}, 2 \mathrm{~b}, 2 \mathrm{~d}$ ) and double decomposition (sample $4 \mathrm{c}^{*}$ ) groups. $\mathrm{C}-\mathrm{S}-\mathrm{H} d$-spacings are noted above their respective peaks in units of $\mathrm{nm}$; peaks associated with $\mathrm{CH}$ are marked with asterisks. $\mathrm{Cu} \mathrm{K} \square$ radiation was used.

Figure 6. ${ }^{29} \mathrm{Si}$ NMR spectra for selected samples from the (a) $\mathrm{C}_{3} \mathrm{~S}$ and (b) double decomposition groups. $\mathrm{Ca} / \mathrm{Si}$ ratios of the solids and sample numbers (in parenthesis) are noted.

Figure 7. Mean silicate chain lengths determined from ${ }^{29} \mathrm{Si}$ NMR data for samples of the $\mathrm{C}_{3} \mathrm{~S}$ (circles) and double decomposition (squares) groups. Unfilled and dotted points approach equilibrium by decalcification, filled and partially filled points by recalcification; slashed circles (_) represent a series of $\mathrm{C}_{3} \mathrm{~S}$ pastes leached in $\mathrm{NH}_{4} \mathrm{NO}_{3}$ solution (Series N). See Tables 2 and 3 for further details on symbols.

Figure 8. Changes in chemical shift of the $\mathrm{Q}^{1}\left({ }_{(}\right)$and $\mathrm{Q}^{2}\left(_{(}\right)$Si sites as a function of $\mathrm{Ca} / \mathrm{Si}$ ratio in $\mathrm{C}-\mathrm{S}-\mathrm{H}$ of the $\mathrm{C}_{3} \mathrm{~S}$ group.

Figure 9. Measured (symbols) and computed (lines) $\mathrm{pH}$ values of aqueous solutions in equilibrium with solids from the $\mathrm{C}_{3} \mathrm{~S}$ (circles, solid line) and double decomposition (squares, dashed line) groups. See Tables 2 and 3 for further details on symbols.

Figure 10. Published solubility data in the $\mathrm{CaO}-\mathrm{SiO}_{2}-\mathrm{H}_{2} \mathrm{O}$ system at room temperature. Unfilled points refer to equilibria associated with metastable $\mathrm{C}-\mathrm{S}-\mathrm{H}$ phases; filled points refer to equilibria occurring during the early hydration of $\mathrm{C}_{3} \mathrm{~S}$. $\mathrm{Ca} / \mathrm{Si}$ ratios of selected solids are noted, and those in parenthesis denote samples containing $\mathrm{C}-\mathrm{S}-\mathrm{H}$ and $\mathrm{CH}$. 
Table 1. Preparation of samples for the phase equilibrium experiments. Equilibrium was approached by decalcifying a high $\mathrm{Ca} / \mathrm{Si}$ solid or by recalcifying a low $\mathrm{Ca} / \mathrm{Si}$ solid; the latter approach is denoted by an asterisk.

\begin{tabular}{|c|c|c|}
\hline Precursor & Series & Procedure \\
\hline \multirow{3}{*}{$\mathrm{C}_{3} \mathrm{~S}$ paste } & 1 & $\begin{array}{l}\text { Pastes, in their saturated state, were lightly crushed, then equilibrated in } \\
\mathrm{H}_{2} \mathrm{O} \text {. }\end{array}$ \\
\hline & 2 & $\begin{array}{l}\text { Pastes were leached in } \mathrm{NH}_{4} \mathrm{NO}_{3} \text { solutions to } \mathrm{Ca} / \mathrm{Si} \text { ratios between } 0.1 \text { and } \\
2.0 \text {, rinsed in } \mathrm{H}_{2} \mathrm{O} \text {, crushed, and then equilibrated in } \mathrm{H}_{2} \mathrm{O} \text {. }\end{array}$ \\
\hline & $3^{*}$ & $\begin{array}{l}\text { Pastes were leached in } \mathrm{NH}_{4} \mathrm{NO}_{3} \text { solution to } \mathrm{Ca} / \mathrm{Si}=1.09 \text {, rinsed in } \mathrm{H}_{2} \mathrm{O} \text {, } \\
\text { crushed, and then equilibrated in } \mathrm{CH} \text { solutions of various concentrations. }\end{array}$ \\
\hline \multirow{3}{*}{$\begin{array}{c}\text { Double } \\
\text { decomposition of } \\
\mathrm{Ca}\left(\mathrm{NO}_{3}\right)_{2} \text { and } \\
\mathrm{Na}_{2} \mathrm{SiO}_{3}\end{array}$} & 4 & $\mathrm{C}-\mathrm{S}-\mathrm{H}$, initially of $\mathrm{Ca} / \mathrm{Si}=1.40$, was equilibrated in $\mathrm{H}_{2} \mathrm{O}$ or $\mathrm{CH}$ solution. \\
\hline & $5^{*}$ & $\begin{array}{l}\mathrm{C}-\mathrm{S}-\mathrm{H} \text {, initially of } \mathrm{Ca} / \mathrm{Si}=1.40 \text {, was leached in } \mathrm{NH}_{4} \mathrm{NO}_{3} \text { solution to } \\
\mathrm{Ca} / \mathrm{Si}=0.55 \text {, rinsed, and then equilibrated in } \mathrm{CH} \text { solutions of various } \\
\text { concentrations. }\end{array}$ \\
\hline & $6^{*}$ & $\begin{array}{l}\mathrm{C}-\mathrm{S}-\mathrm{H} \text {, initially of } \mathrm{Ca} / \mathrm{Si}=1.40 \text {, was leached in } \mathrm{H}_{2} \mathrm{O} \text { by placing } \sim 50 \mathrm{~g} \text { of } \\
\text { sample in } 500 \mathrm{~mL} \text { of } \mathrm{H}_{2} \mathrm{O} \text {. The mixture was repeatedly decanted and } \\
\text { replaced with fresh } \mathrm{H}_{2} \mathrm{O} \text { for a total period of } 12 \text { days until the } \mathrm{Ca} / \mathrm{Si} \text { ratio } \\
\text { reached } 1.05 \text {. The solid was then equilibrated in } \mathrm{CH} \text { solutions of various } \\
\text { concentrations. }\end{array}$ \\
\hline
\end{tabular}


Table 2. Phase equilibrium results for the $\mathrm{C}_{3} \mathrm{~S}$ group. Symbols used in subsequent figures are shown; unfilled and dotted points approach equilibrium by decalcification, filled and partially filled points (see Table 3) by recalcification. The 'initial $\mathrm{Ca} / \mathrm{Si}$ ' ratio is that of the solid before equilibration; all other values are measured at equilibrium. Dashes indicate an undetermined measurement.

\begin{tabular}{|c|c|c|c|c|c|c|c|c|c|}
\hline & Series & Sample & Symbol & $\begin{array}{l}\text { Initial } \\
\mathrm{Ca} / \mathrm{Si}\end{array}$ & $\begin{array}{l}{[\mathrm{Ca}]} \\
(\mathrm{mM}) \\
\end{array}$ & $\begin{array}{c}{[\mathrm{Si}]} \\
(\square \mathrm{M})\end{array}$ & $\mathrm{pH}$ & $\begin{array}{l}\text { Final } \\
\mathrm{Ca} / \mathrm{Si}\end{array}$ & Phases present ${ }^{a}$ \\
\hline \multirow{8}{*}{1} & \multirow{8}{*}{ Equilibrated in $\mathrm{H}_{2} \mathrm{O}$} & $1 \mathrm{a}$ & _- & 3.00 & 20.83 & 48.9 & - & 3.00 & $\mathrm{C}-\mathrm{S}-\mathrm{H}, \mathrm{CH}$ \\
\hline & & $1 b$ & _- & 3.00 & 20.59 & 41.5 & - & 2.99 & - \\
\hline & & $1 \mathrm{c}$ & _- & 3.00 & 19.22 & 47.1 & - & 2.64 & - \\
\hline & & $1 d$ & - & 3.00 & 18.59 & 45.7 & 12.49 & 2.42 & $\mathrm{C}-\mathrm{S}-\mathrm{H}, \mathrm{CH}$ \\
\hline & & $1 \mathrm{e}$ & - & 3.00 & 15.86 & 51.1 & 12.43 & 1.87 & $\mathrm{C}-\mathrm{S}-\mathrm{H}, \mathrm{CH}$ \\
\hline & & $1 \mathrm{f}$ & - & 3.00 & 15.22 & 59.3 & - & 1.81 & - \\
\hline & & $1 \mathrm{~g}$ & 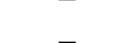 & 3.00 & 13.57 & 59.3 & - & 1.75 & $\mathrm{C}-\mathrm{S}-\mathrm{H}, \mathrm{CH}$ \\
\hline & & $1 \mathrm{~h}$ & & 3.00 & 3.17 & 150.7 & 11.69 & 1.05 & - \\
\hline \multirow{7}{*}{$\begin{array}{rr}2 \mathrm{I} \\
\mathrm{s} \\
\mathrm{i}\end{array}$} & \multirow{7}{*}{$\begin{array}{l}\text { Leached in } \mathrm{NH}_{4} \mathrm{NO}_{3} \\
\text { solution, then equilibrated } \\
\text { in } \mathrm{H}_{2} \mathrm{O}\end{array}$} & $2 \mathrm{a}$ & - & 2.04 & 8.59 & 66.4 & 12.21 & 1.40 & - \\
\hline & & $2 b$ & - & 1.56 & 7.20 & 66.4 & 12.12 & 1.27 & $\mathrm{C}-\mathrm{S}-\mathrm{H}$ \\
\hline & & $2 \mathrm{c}$ & - & 1.21 & 3.37 & 164.3 & 11.79 & 1.06 & - \\
\hline & & $2 d$ & - & 0.98 & 1.73 & 635.3 & 11.16 & 0.89 & $\mathrm{C}-\mathrm{S}-\mathrm{H}$ \\
\hline & & $2 \mathrm{e}$ & - & 0.74 & 1.27 & 2303.6 & 10.13 & 0.74 & - \\
\hline & & $2 \mathrm{f}$ & _ & 0.56 & 0.95 & 2890.7 & 9.97 & 0.62 & $\mathrm{C}-\mathrm{S}-\mathrm{H}$ \\
\hline & & $2 \mathrm{~g}$ & - & 0.11 & 0.30 & 2565.7 & 9.53 & 0.11 & $\mathrm{C}-\mathrm{S}-\mathrm{H}, \mathrm{SiO}_{2}$ gel \\
\hline \multirow{7}{*}{\multicolumn{2}{|c|}{$\begin{array}{l}3^{*} \text { Leached in } \mathrm{NH}_{4} \mathrm{NO}_{3} \\
\text { solution, then equilibrated } \\
\text { in } \mathrm{CH} \text { solution }\end{array}$}} & $3 a^{*}$ & - & 1.09 & 2.37 & 271.1 & 11.63 & 1.08 & - \\
\hline & & $3 b^{*}$ & - & 1.09 & 4.81 & 93.6 & 11.97 & 1.22 & - \\
\hline & & $3 c^{*}$ & - & 1.09 & 7.36 & 82.1 & 12.15 & 1.33 & $\mathrm{C}-\mathrm{S}-\mathrm{H}$ \\
\hline & & $3 d^{*}$ & - & 1.09 & 8.31 & 69.3 & 12.10 & 1.45 & - \\
\hline & & $3 e^{*}$ & - & 1.09 & 13.08 & 52.5 & 12.25 & 1.58 & - \\
\hline & & $3 \mathrm{f}^{*}$ & - & 1.09 & 15.90 & 41.1 & - & 1.70 & $\mathrm{C}-\mathrm{S}-\mathrm{H}$ \\
\hline & & $3 \mathrm{~g}^{*}$ & & 1.09 & 20.59 & 41.5 & 12.46 & 1.87 & $\mathrm{C}-\mathrm{S}-\mathrm{H}$ \\
\hline \multirow{5}{*}{\multicolumn{2}{|c|}{$\begin{array}{l}\mathrm{N} \\
\text { Leached in } \mathrm{NH}_{4} \mathrm{NO}_{3} \\
\text { solution }\end{array}$}} & N1 & - & 3.00 & - & - & - & 1.86 & - \\
\hline & & $\mathrm{N} 2$ & - & 3.00 & - & - & - & 1.39 & - \\
\hline & & N3 & - & 3.00 & - & - & - & 1.08 & - \\
\hline & & N4 & - & 3.00 & - & - & - & 0.70 & - \\
\hline & & N5 & - & 3.00 & - & - & - & 0.17 & - \\
\hline
\end{tabular}

${ }^{a}$ Determined by XRD.

Table 3. Phase equilibrium results for the double decomposition group. See heading of Table 2 for details.

\begin{tabular}{|c|c|c|c|c|c|c|c|c|c|}
\hline & Series & Sample & Symbol & $\begin{array}{l}\text { Initial } \\
\mathrm{Ca} / \mathrm{Si}\end{array}$ & $\begin{array}{c}{[\mathrm{Ca}]} \\
(\mathrm{mM})\end{array}$ & $\begin{array}{c}{[\mathrm{Si}]} \\
(\mathrm{mM})\end{array}$ & $\mathrm{pH}$ & $\begin{array}{l}\mathrm{Final} \\
\mathrm{Ca} / \mathrm{Si}\end{array}$ & Phases present \\
\hline \multirow[t]{3}{*}{4} & Equilibrated in $\mathrm{H}_{2} \mathrm{O}$ or $\mathrm{CH}$ & $4 a^{*}$ & 5 & 1.40 & 19.27 & 16.8 & 12.37 & 1.48 & $\mathrm{C}-\mathrm{S}-\mathrm{H}$ \\
\hline & solution $^{a}$ & $4 b^{*}$ & - & 1.40 & 19.18 & 13.2 & - & - & - \\
\hline & & $4 c^{*}$ & & 1.40 & 17.82 & 15.9 & 12.16 & 1.44 & - \\
\hline
\end{tabular}




\begin{tabular}{ccccccccc} 
& $4 \mathrm{~d}$ & - & 1.40 & 9.96 & 20.4 & 11.88 & 1.31 & - \\
& $4 \mathrm{e}$ & - & 1.40 & 5.08 & 44.1 & 11.70 & 1.20 & - \\
& $4 \mathrm{f}$ & - & 1.40 & 3.13 & 84.9 & - & - & - \\
& $4 \mathrm{~g}$ & - & 1.40 & 2.70 & 97.3 & 11.46 & 1.03 & - \\
$4 \mathrm{~h}$ & - & 1.40 & 2.03 & 144.0 & 11.56 & 1.05 & - \\
& $4 \mathrm{i}$ & - & 1.40 & 1.66 & 421.6 & 11.16 & 0.92 & $\mathrm{C}-\mathrm{S}-\mathrm{H}$ \\
& $4 \mathrm{j}$ & - & 1.40 & 1.41 & 220.4 & - & 1.03 & - \\
\hline 5 & $4 \mathrm{k}$ & - & 1.40 & 0.86 & 541.4 & - & - & - \\
\hline $5^{*}$ Leached in $\mathrm{NH}_{4} \mathrm{NO}_{3}$ & $5 \mathrm{a}^{*}$ & - & 0.55 & 15.36 & 15.7 & - & 1.45 & - \\
solution, then equilibrated in & $5 \mathrm{~b}^{*}$ & - & 0.55 & 6.25 & 42.5 & - & 1.26 & - \\
$\mathrm{CH}$ solution & $6 \mathrm{a}^{*--}$ & - & 1.05 & 13.85 & 16.6 & 12.33 & 1.35 & - \\
\hline $6^{*}$ Leached in $\mathrm{H}_{2} \mathrm{O}$, then & $6 \mathrm{~b}^{*}$ & - & 1.05 & 7.37 & 32.4 & 12.07 & 1.28 & $\mathrm{C}-\mathrm{S}-\mathrm{H}$ \\
equilibrated in $\mathrm{CH}$ solution & $6 \mathrm{c}^{*}$ & - & 1.05 & 6.09 & 41.9 & 12.03 & 1.26 & - \\
\hline
\end{tabular}

${ }^{a}$ The only samples in Series 4 equilibrated in $\mathrm{CH}$ solution were $4 \mathrm{a}^{*}-4 \mathrm{c}^{*}$.

Table 4. ${ }^{29} \mathrm{Si}$ NMR results for $\mathrm{C}-\mathrm{S}-\mathrm{H}$ of the $\mathrm{C}_{3} \mathrm{~S}$ and double decomposition groups.

\begin{tabular}{lcccccccc} 
Precursor & Sample & $\mathrm{Ca} / \mathrm{Si}$ & $\begin{array}{c}\text { Mean silicate } \\
\text { chain length }^{a}\end{array}$ & $\begin{array}{c}\mathrm{Q}^{1} \\
(\mathrm{ppm})\end{array}$ & $\begin{array}{c}\mathrm{Q}^{2} \\
(\mathrm{ppm})\end{array}$ & $\begin{array}{c}\mathrm{Q}^{2} \\
\text { shoulder } \\
(\mathrm{ppm})\end{array}$ & $\begin{array}{c}\mathrm{Q}^{3}(\mathrm{OH}) \\
(\mathrm{ppm})\end{array}$ & $\begin{array}{c}\mathrm{Q}^{4} \\
(\mathrm{ppm})\end{array}$ \\
\hline \multirow{5}{*}{$\mathrm{C}_{3} \mathrm{~S}$} & $1 \mathrm{a}$ & 3.00 & 2.8 & -78.7 & -84.8 & & & \\
& $\mathrm{n} 1$ & 1.86 & 3.2 & -78.7 & -84.9 & & & \\
& $3 \mathrm{e}^{*}$ & 1.58 & 3.5 & -79.1 & -85.0 & & & \\
& $\mathrm{n} 2$ & 1.39 & 3.9 & -79.0 & -84.9 & & & \\
& $3 \mathrm{~b}^{*}$ & 1.22 & 5.0 & -79.3 & -85.4 & & & \\
& $\mathrm{n} 3$ & 1.08 & 7.1 & -79.1 & -85.2 & -83.1 & & \\
& $\mathrm{n} 4$ & 0.70 & 18.6 & -79.5 & -85.4 & -83.0 & & \\
Double & $\mathrm{n} 5$ & 0.17 & high & & -85.7 & & -101.3 & -109.6 \\
decomposition & $4 \mathrm{c}^{*}$ & 1.44 & 2.6 & -78.5 & -84.3 & & & \\
& $6 \mathrm{c}^{*}$ & 1.28 & 2.9 & -78.7 & -84.7 & -82.2 & & \\
& $5 \mathrm{~b}^{*}$ & 1.26 & 3.0 & -79.4 & -85.2 & & & \\
& $4 \mathrm{~g}$ & 1.03 & 6.1 & -79.1 & -85.1 & -82.8 & & \\
\hline & $4 \mathrm{i}$ & 0.92 & 9.2 & -78.7 & -85.0 & -82.9 & & \\
\hline
\end{tabular}

${ }^{a}$ Calculated as $2\left(\mathrm{Q}^{1}+\mathrm{Q}^{2}\right) / 2$ 
Table 5. Charge balance calculations for the $\mathrm{Ca} / \mathrm{Si}$ ratios above which $\mathrm{Ca}-\mathrm{OH}$ must be present in $\mathrm{C}-\mathrm{S}-\mathrm{H}$. These values correspond to the $\mathrm{Ca} / \mathrm{Si}$ ratios where a departure in solubility from curve A occurs; see text.

\begin{tabular}{ccc}
$\begin{array}{c}\text { Mean silicate } \\
\text { chain length }\end{array}$ & $\begin{array}{c}\text { Formula per } 6 \\
\mathrm{Si} \text { sites }\end{array}$ & $\begin{array}{c}\mathrm{Ca} / \mathrm{Si} \text { ratio above which } \\
\mathrm{Ca}-\mathrm{OH} \text { must be present }\end{array}$ \\
\hline 2 & $\mathrm{Ca}_{6} \mathrm{Si}_{4} \mathrm{O}_{14}$ & 1.50 \\
3 & $\mathrm{Ca}_{6} \mathrm{Si}_{4.5} \mathrm{O}_{15}$ & 1.33 \\
4 & $\mathrm{Ca}_{6} \mathrm{Si}_{4.8} \mathrm{O}_{15.6}$ & 1.25 \\
5 & $\mathrm{Ca}_{6} \mathrm{Si}_{5} \mathrm{O}_{16}$ & 1.20 \\
& $\mathrm{Ca}_{6} \mathrm{Si}_{6} \mathrm{O}_{18}$ & 1.00 \\
\hline
\end{tabular}

${ }^{a}$ Molecular water is omitted.

Table 6. Published $\mathrm{Ca} / \mathrm{Si}$ ratios in $\mathrm{C}-\mathrm{S}-\mathrm{H}$ determined at $\mathrm{CH}$ saturation. All values were measured after equilibrating at $17-30^{\circ} \mathrm{C}$; initial preparation temperatures outside this range are noted.

\begin{tabular}{|c|c|c|c|c|c|}
\hline $\begin{array}{l}\text { Method of } \\
\text { preparation }\end{array}$ & Author(s) & Ref. No. & Starting materials & $\begin{array}{c}\mathrm{Ca} / \mathrm{Si} \text { at } \\
\mathrm{CH} \\
\text { saturation }\end{array}$ & $\begin{array}{l}\text { Solubility curve } \\
\text { at high } \mathrm{Ca} \\
\text { concentration }\end{array}$ \\
\hline \multirow{5}{*}{$\begin{array}{l}\text { Double } \\
\text { decomposition }\end{array}$} & Bessey & {$[91]$} & $\mathrm{Na}_{2} \mathrm{SiO}_{3}+\mathrm{Ca}\left(\mathrm{NO}_{3}\right)_{2}$ & 1.5 & - \\
\hline & Taylor & [21] & $\mathrm{Na}_{2} \mathrm{SiO}_{3}+\mathrm{Ca}\left(\mathrm{NO}_{3}\right)_{2}$ & 1.5 & A \\
\hline & Fujii \& Kondo & [78] & $\mathrm{Na}_{2} \mathrm{SiO}_{3}+\mathrm{Ca}\left(\mathrm{NO}_{3}\right)_{2}$ & 1.5 & Below A \\
\hline & Current study & - & $\mathrm{Na}_{2} \mathrm{SiO}_{3}+\mathrm{Ca}\left(\mathrm{NO}_{3}\right)_{2}$ & 1.5 & $\mathrm{C}^{\prime \prime}$ \\
\hline & Roller \& Ervin & [76] & $\mathrm{Na}_{2} \mathrm{SiO}_{3}+\mathrm{CH}$ & 1.45 & $\mathrm{C}^{\prime \prime}$ \\
\hline \multirow{8}{*}{$\begin{array}{l}\text { Lime and silica } \\
\text { suspensions }\end{array}$} & Baylis & [92] & $\mathrm{CaO}+\mathrm{SiO}_{2}$ & 1.5 & - \\
\hline & van der Burgh & [93] & $\mathrm{CaO}+\mathrm{SiO}_{2}$ & 1.4 & - \\
\hline & Shaw \& MacIntire & [94] & $\mathrm{CaO}+\mathrm{SiO}_{2}$ & 1.4 & - \\
\hline & Le Chatelier & [45] & $\mathrm{CH}+\mathrm{SiO}_{2}$ & 1.7 & - \\
\hline & Flint \& Wells & [75] & $\mathrm{CH}+\mathrm{SiO}_{2}$ & 1.7 & $\mathrm{C}^{\prime}$ \\
\hline & Kalousek & [74] & $\mathrm{CH}+\mathrm{SiO}_{2}$ & $\begin{array}{l}1.3 \text { or } \\
1.75^{a}\end{array}$ & $\mathrm{C}$ \\
\hline & Cong \& Kirkpatrick & [3] & $\mathrm{CH}+\mathrm{SiO}_{2}$ & 1.6 & - \\
\hline & Greenberg \& Chang & [52] & $\mathrm{CH}+\mathrm{SiO}_{2}, 50^{\circ} \mathrm{C}$ & 1.75 & $\mathrm{C}^{\prime \prime}$ \\
\hline \multirow{8}{*}{$\begin{array}{l}\text { Anhydrous } \\
\text { calcium } \\
\text { silicates }\end{array}$} & Kühl \& Mann & [95] & $\mathrm{CaO} / \mathrm{SiO}_{2}$ melt & 1.5 & - \\
\hline & Cong \& Kirkpatrick & [3] & Reactive $\mathrm{C}_{2} \mathrm{~S}$ & 1.6 & - \\
\hline & Thorvaldson \& Vigfusson & [96] & $\mathrm{C}_{2} \mathrm{~S}, \mathrm{C}_{3} \mathrm{~S}$ & 1.45 & - \\
\hline & Nonat \& Lecoq & [53] & $\mathrm{C}_{3} \mathrm{~S}$ & 1.5 & - \\
\hline & Cirilli & [97] & $\mathrm{C}_{3} \mathrm{~S}$ & 1.4 & - \\
\hline & Taylor & [21] & $\mathrm{C}_{3} \mathrm{~S}$ (2 points) & 1.6 & - \\
\hline & Greenberg \& Chang & [52] & Mature $\mathrm{C}_{3} \mathrm{~S}$ paste & 1.75 & $\mathrm{~A}, \mathrm{C} ", \mathrm{C}$ \\
\hline & Current study & - & Mature $\mathrm{C}_{3} \mathrm{~S}$ paste & 1.8 & $\mathrm{C}$ \\
\hline
\end{tabular}

${ }^{a}$ Although the lower value is often cited, XRD showed evidence near $20 \mathrm{mM}$ Ca for a single-phase C-S-H sample with $\mathrm{Ca} / \mathrm{Si}=1.7-1.8$. Some of the $\mathrm{Ca} / \mathrm{Si}$ ratios determined from the initial and final concentrations in solution also suggest values higher than 1.3. 


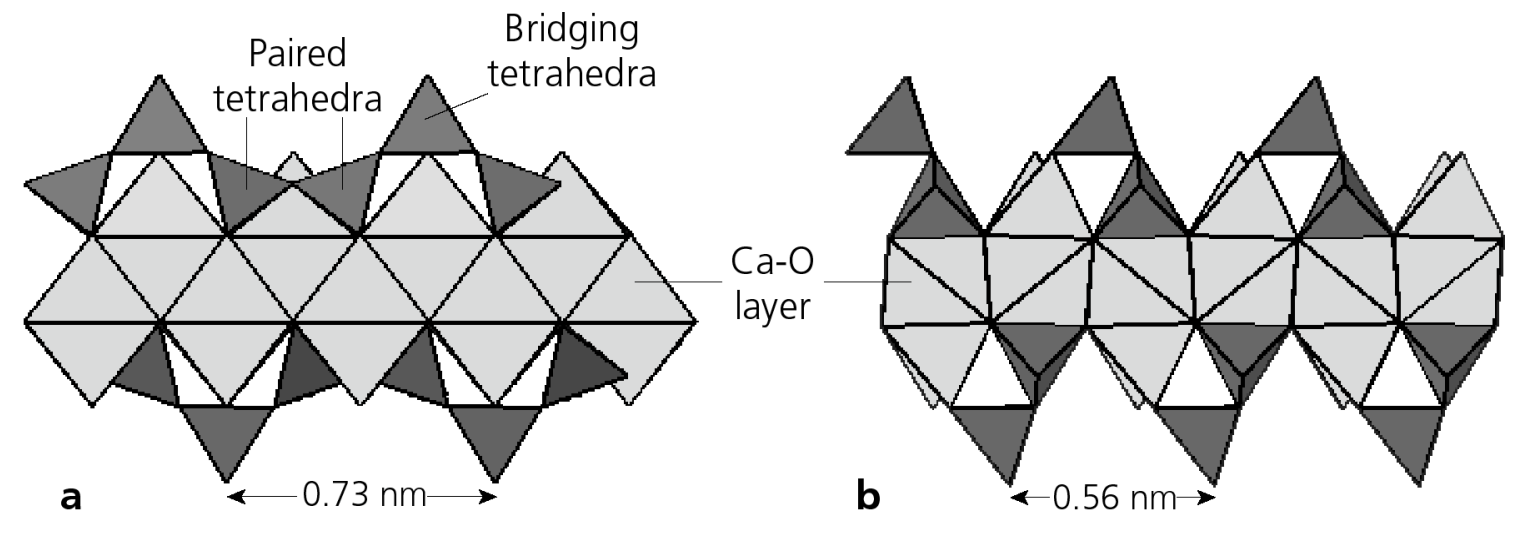

Figure 1 


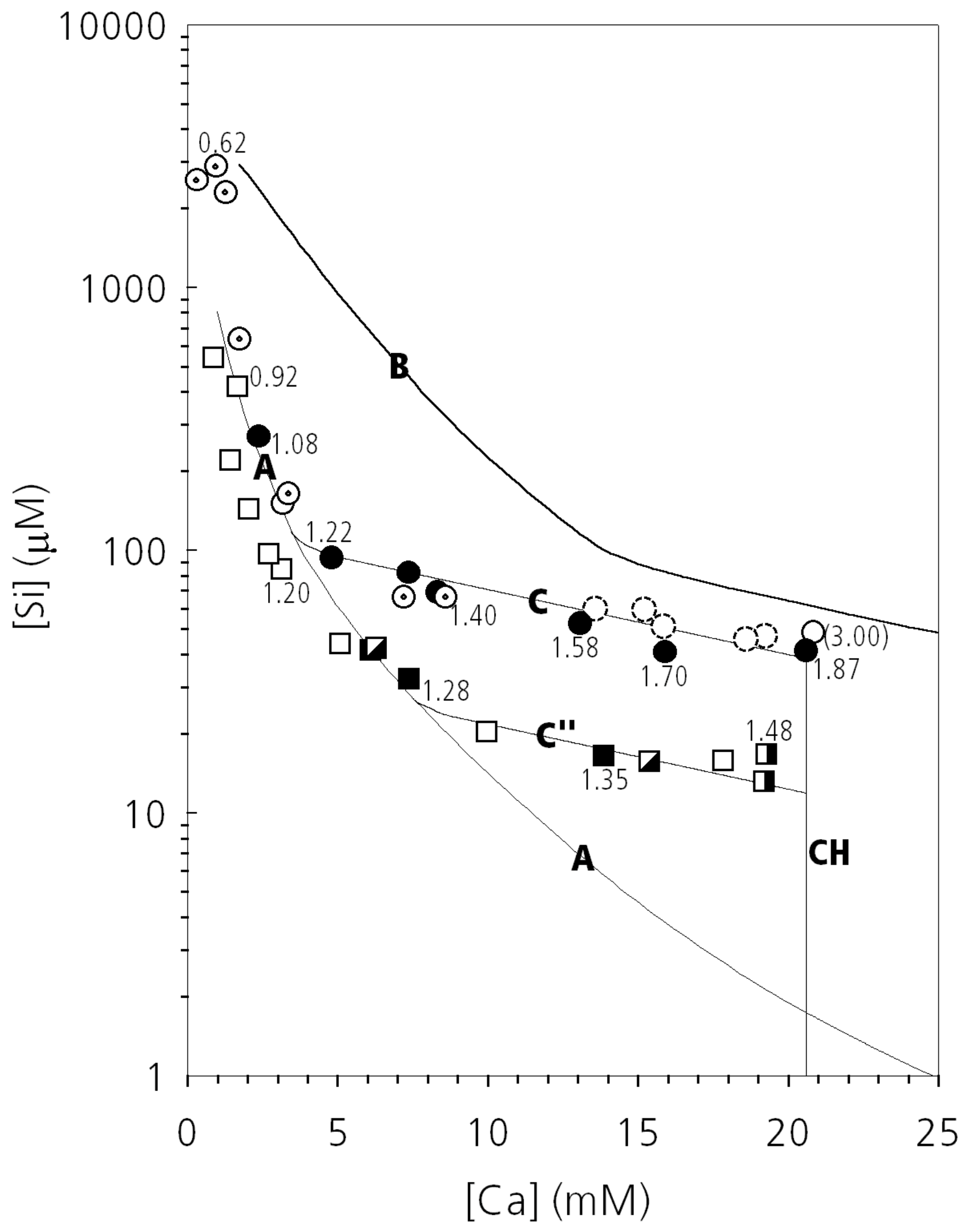

Figure 2 


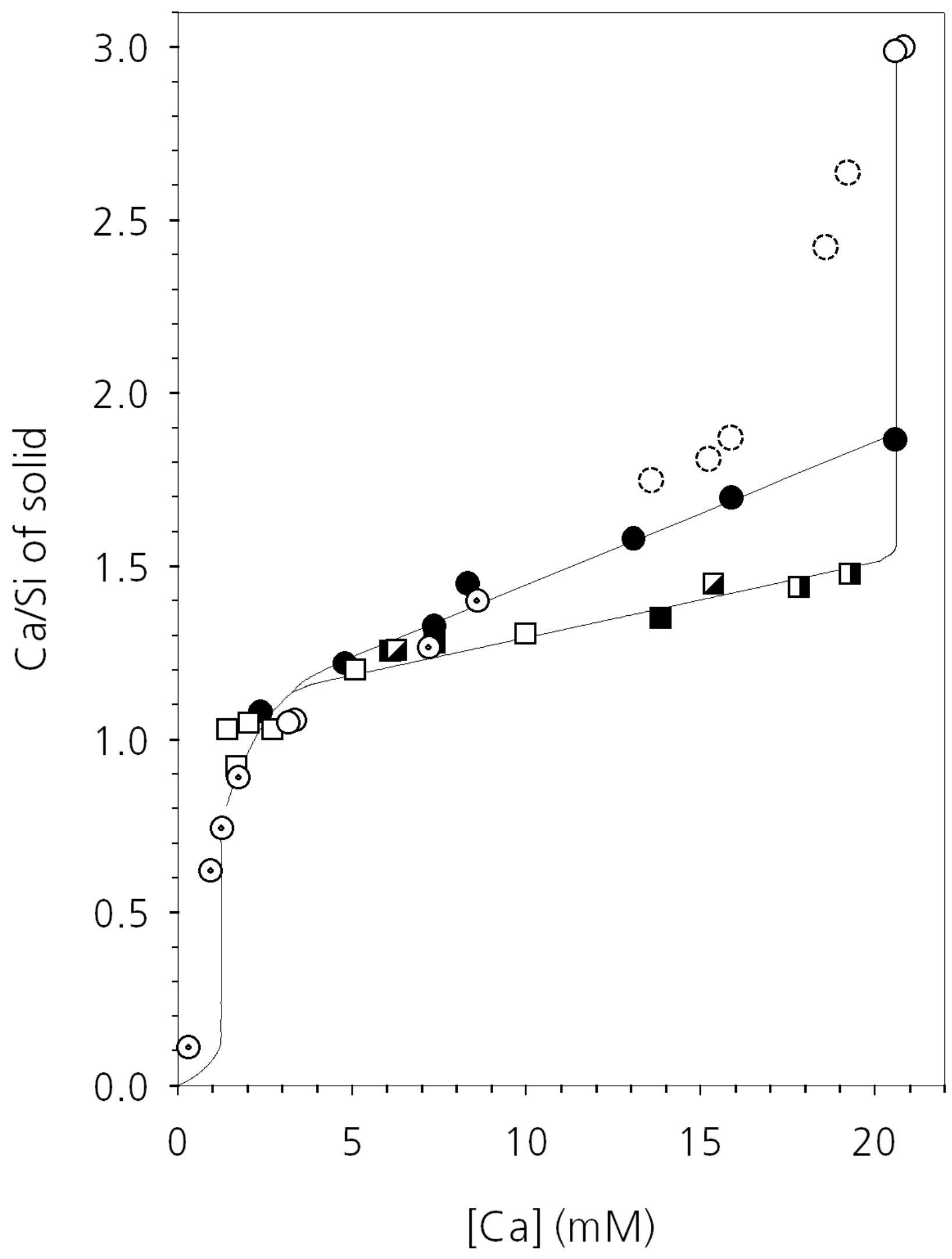

Figure 3 


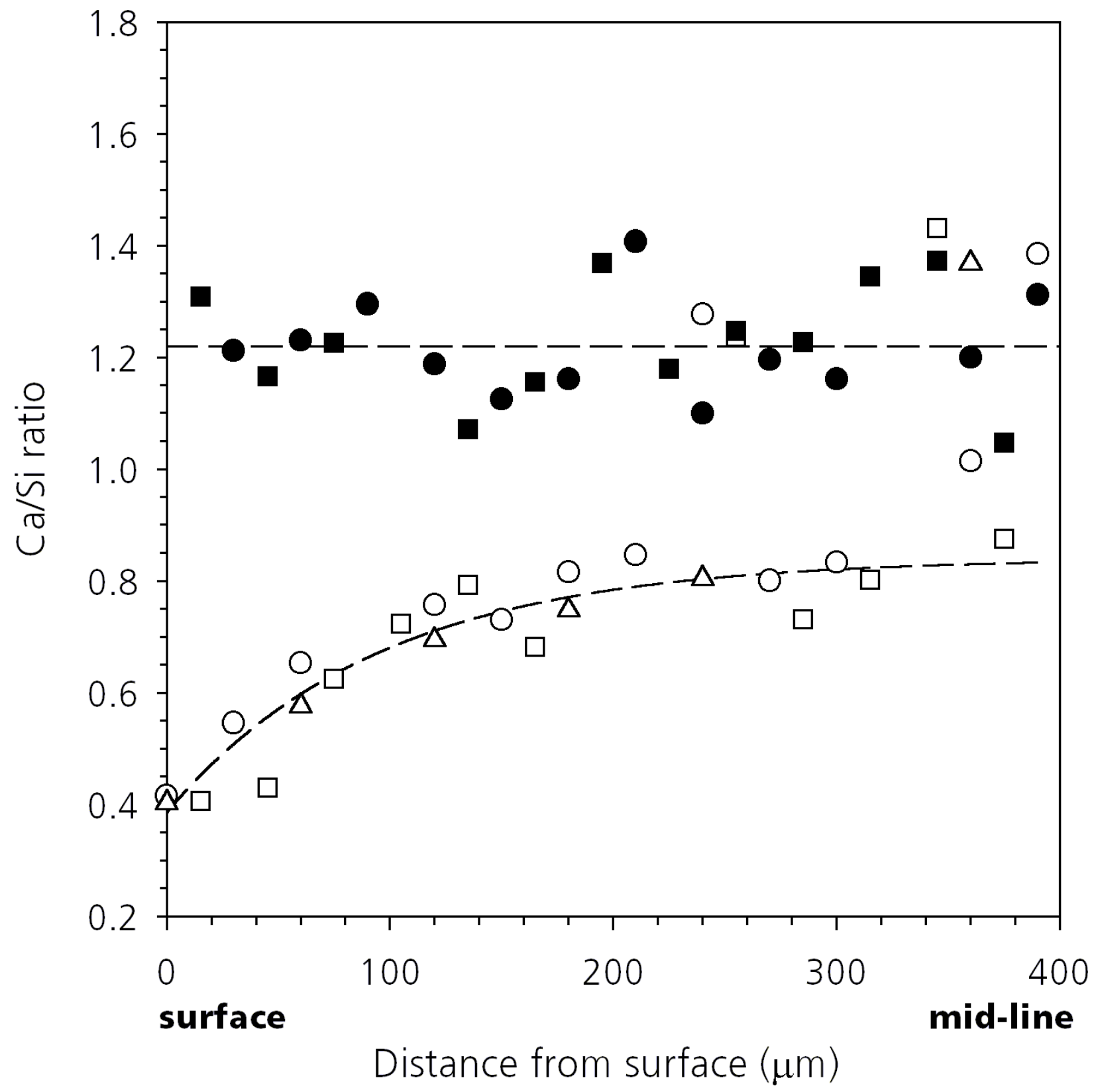

Figure 4 


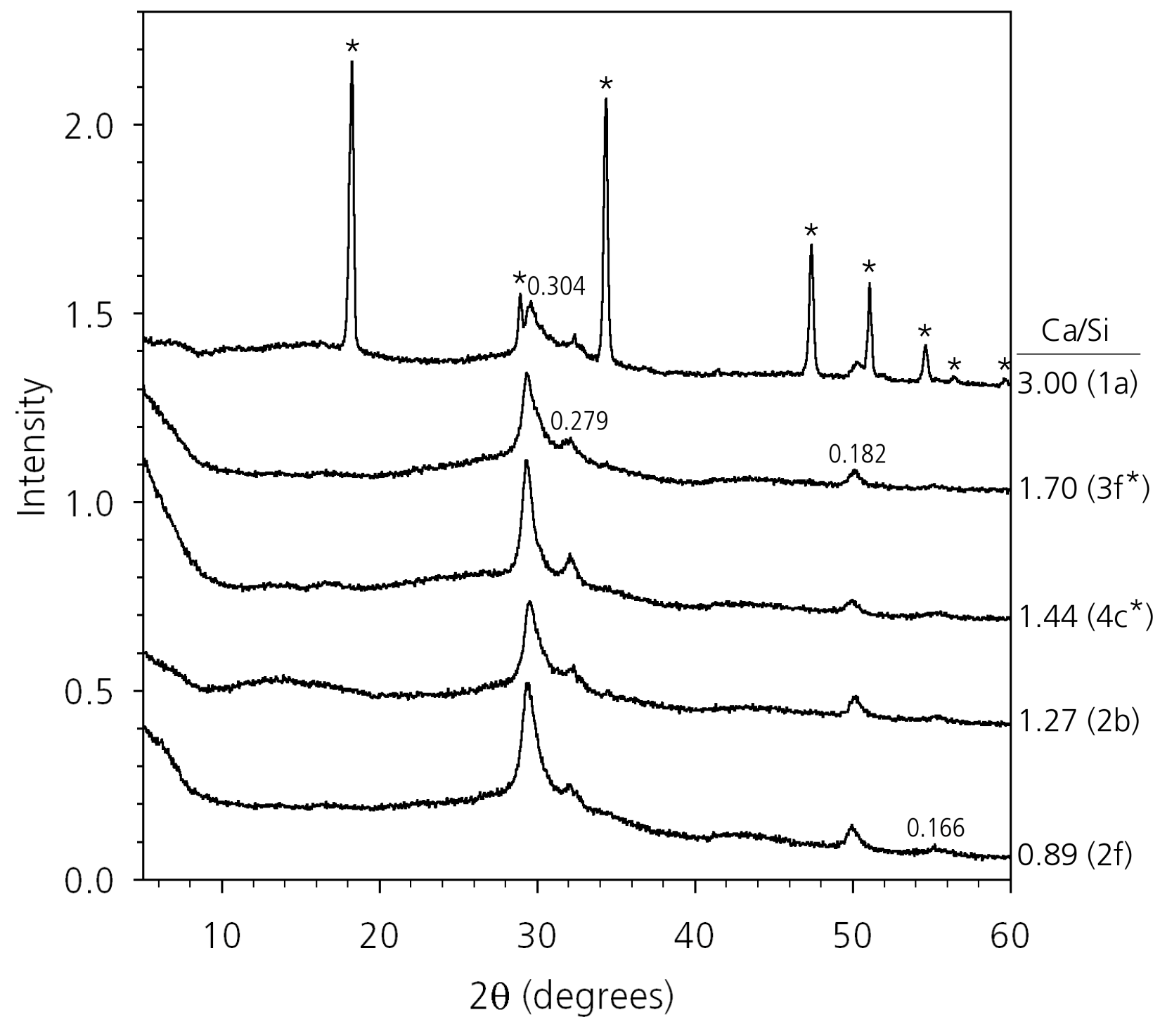

Figure 5 


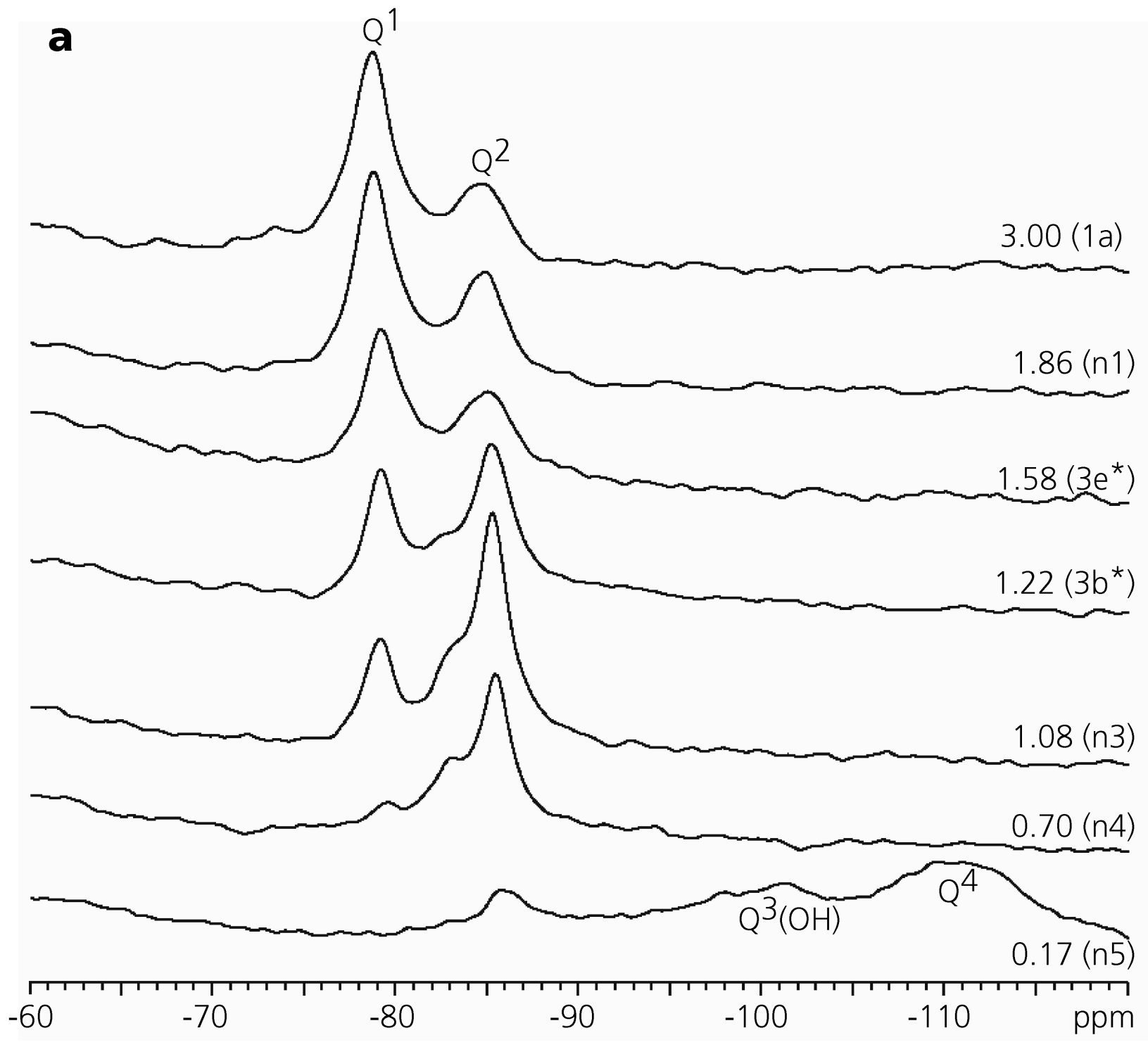

Figure 6a 


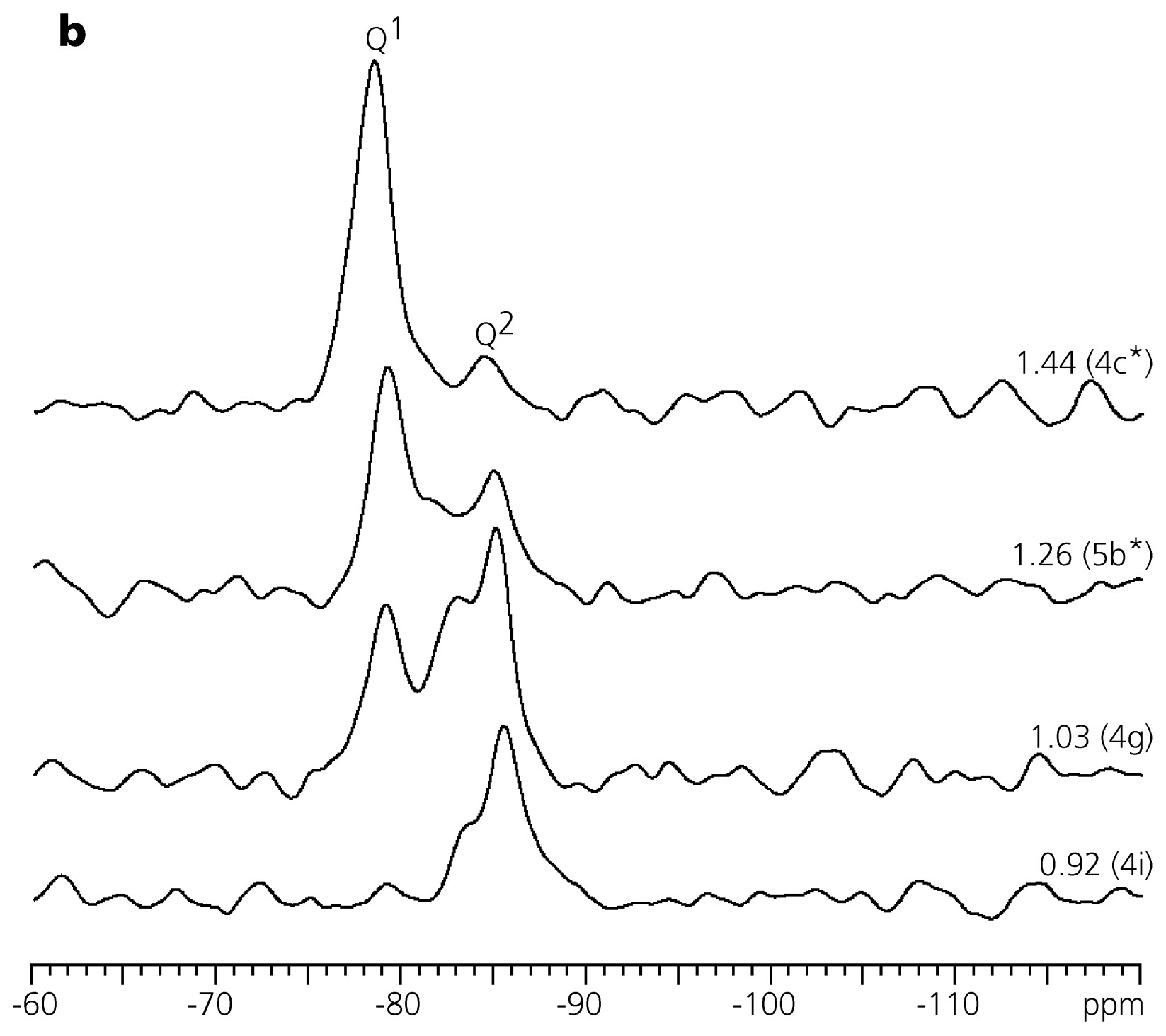

Figure 6b 


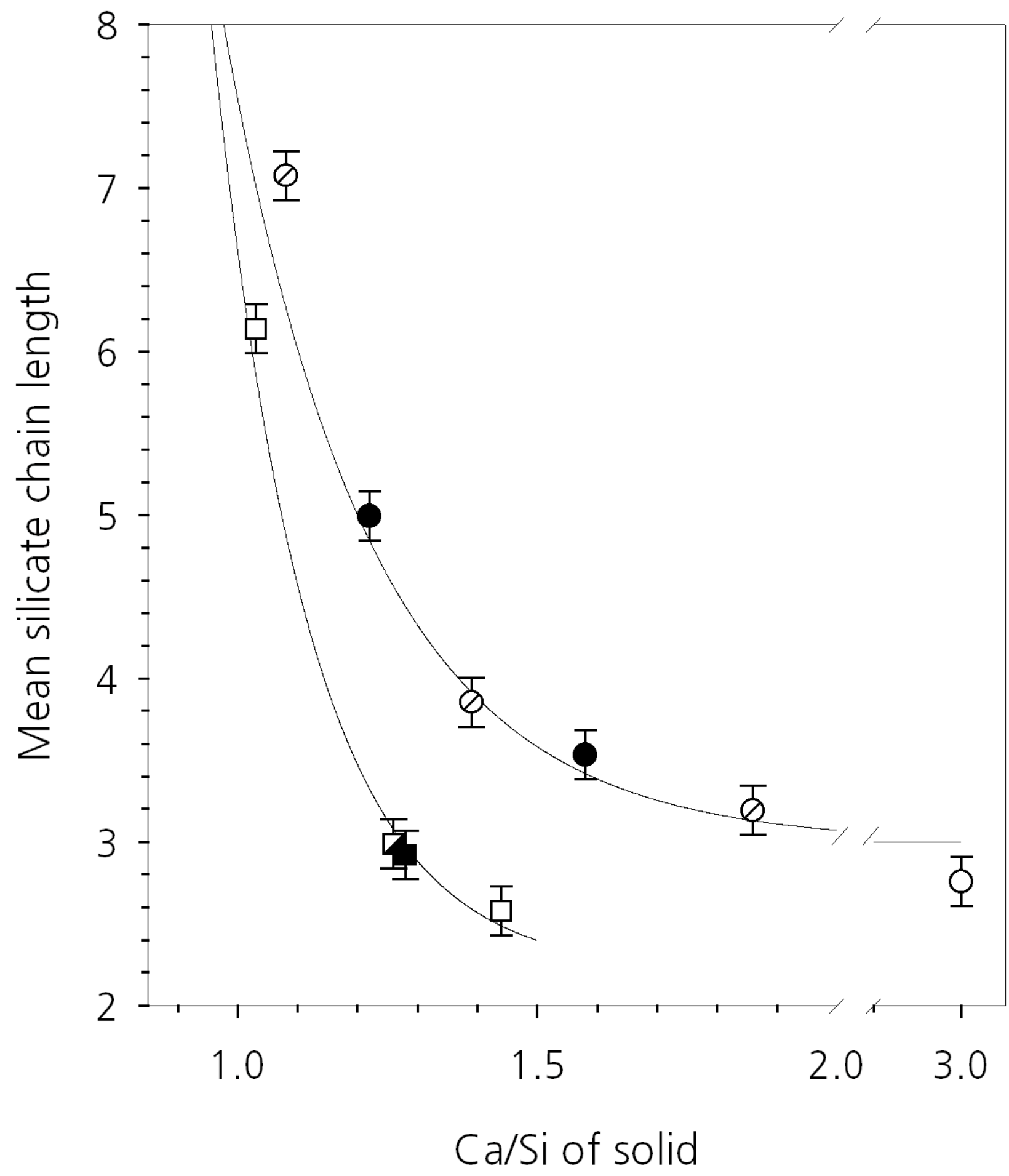

Figure 7 


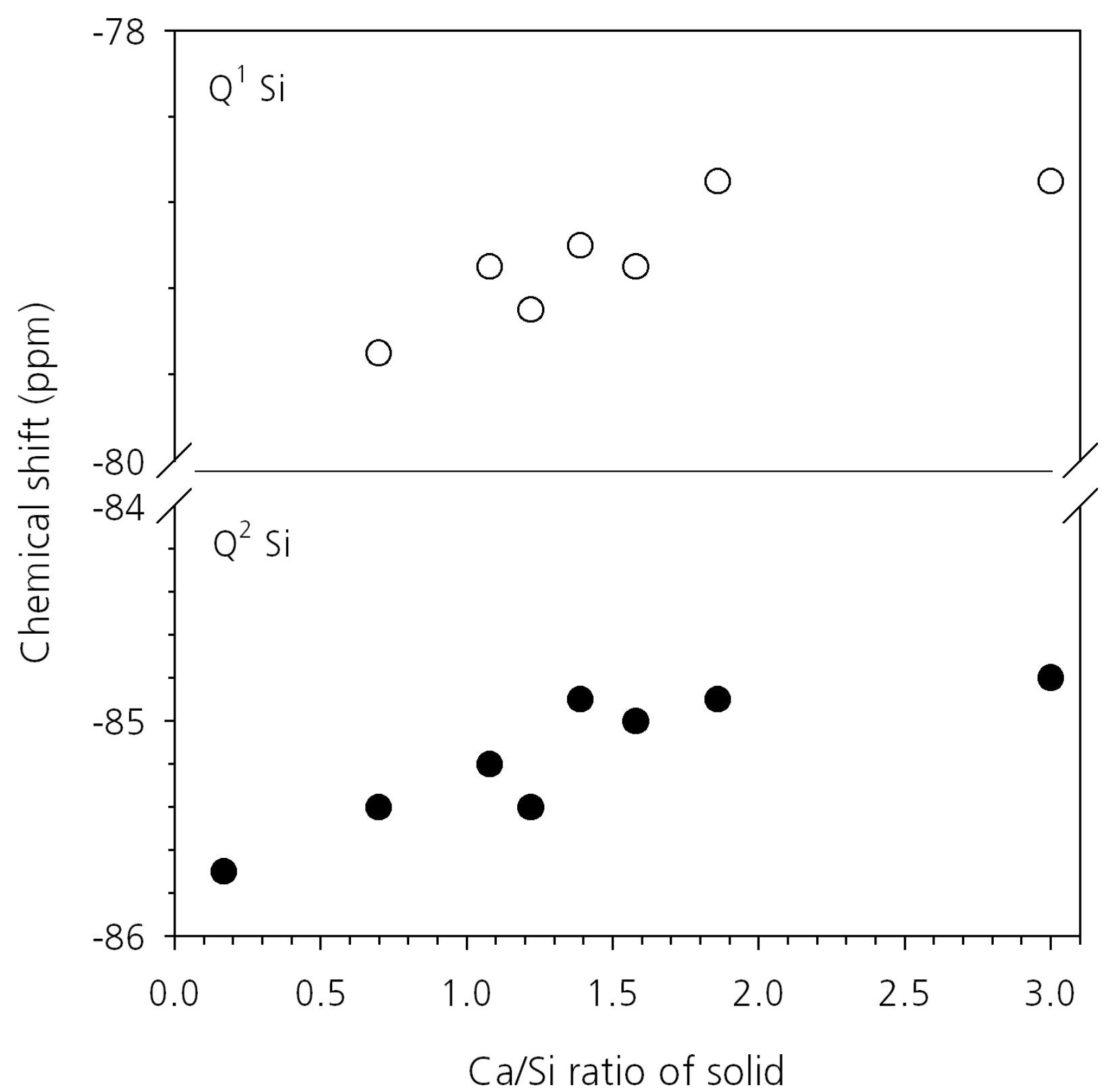

Figure 8 


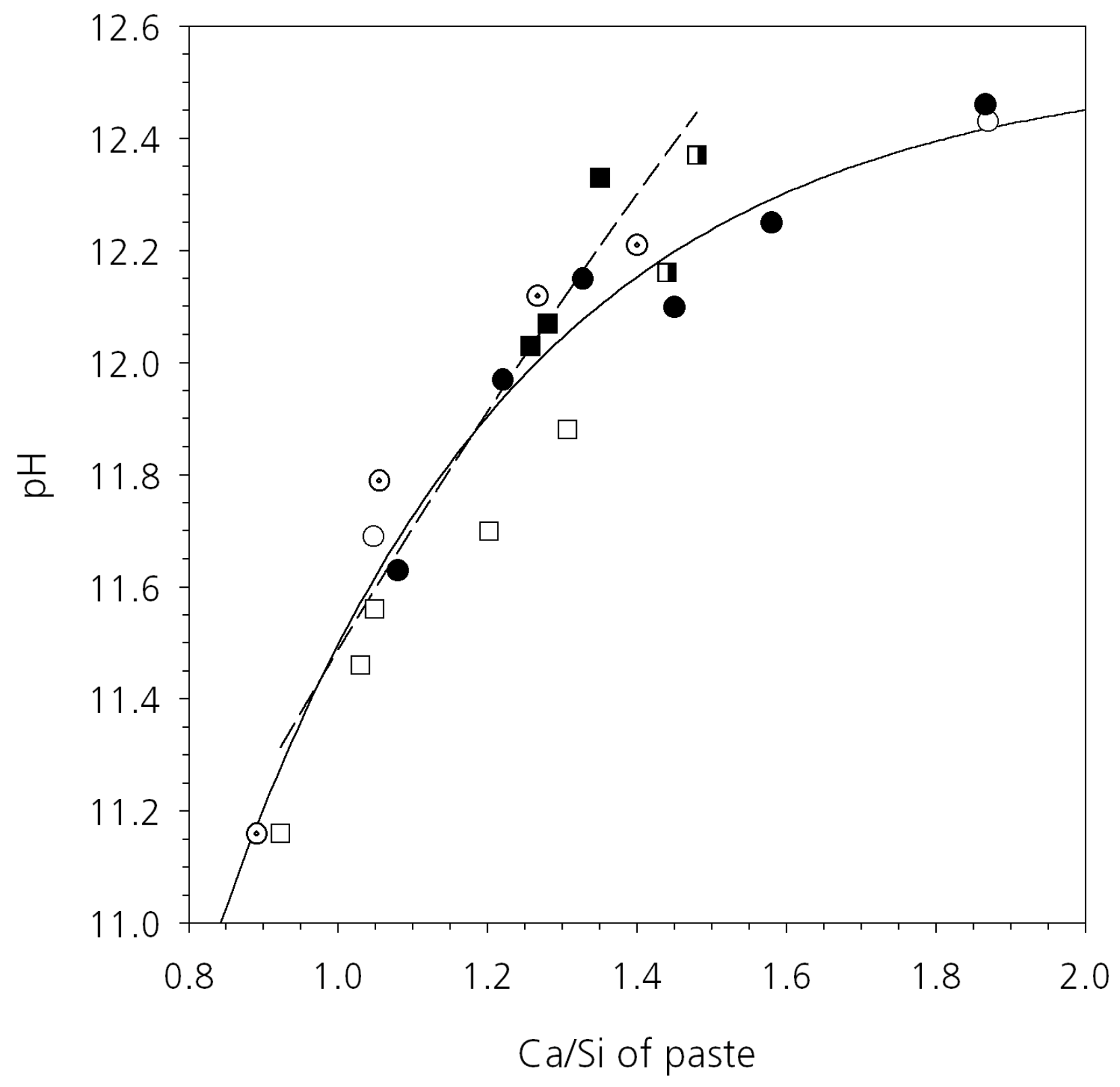

Figure 9 


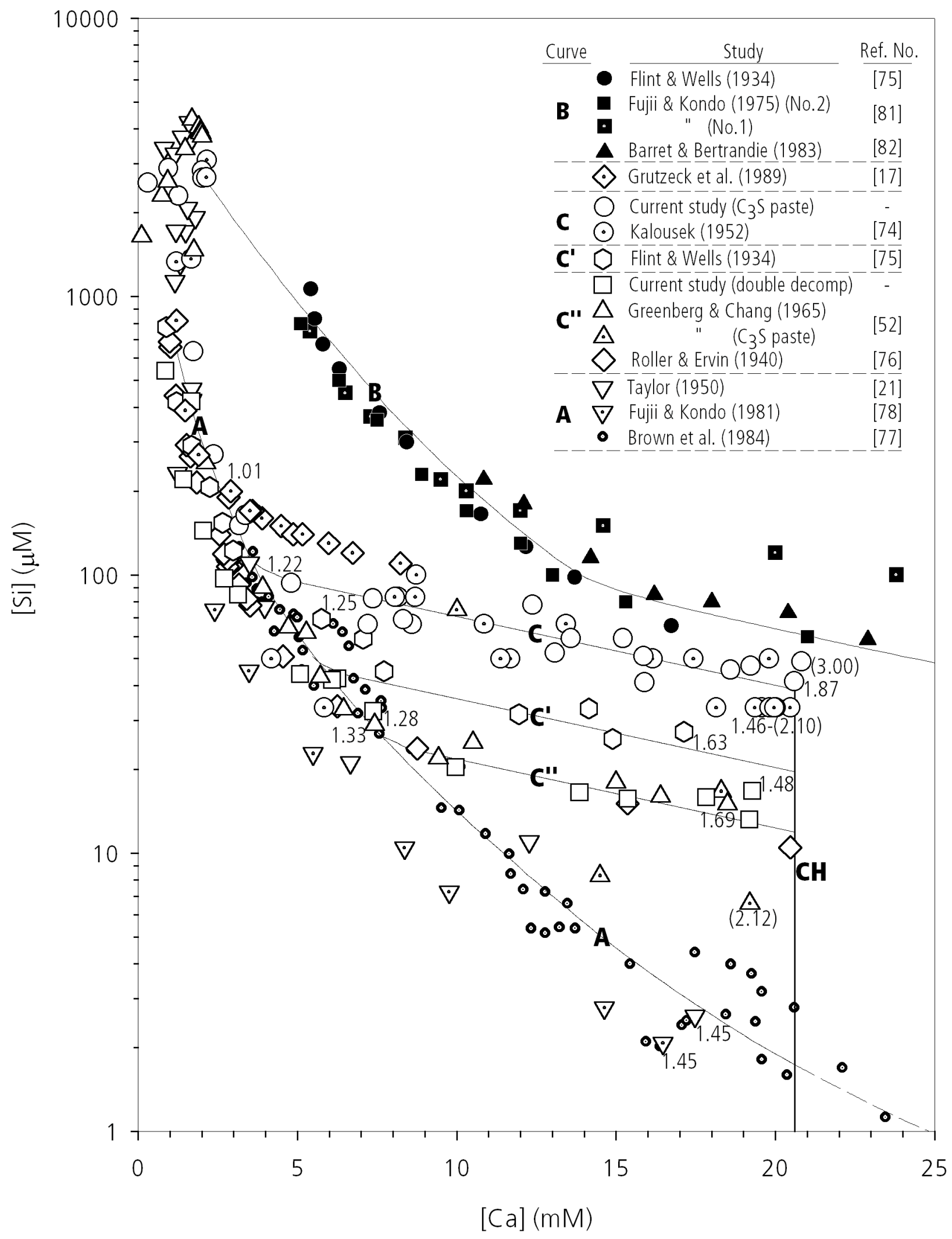

Figure 10 